Review

\title{
Tropism of the Chikungunya Virus
}

\author{
Giulia Matusali *(D), Francesca Colavita *, Licia Bordi, Eleonora Lalle, Giuseppe Ippolito ${ }^{\circ}$, \\ Maria R. Capobianchi and Concetta Castilletti 1
}

\author{
National Institute for Infectious Diseases “Lazzaro Spallanzani” IRCCS, 00149 Rome, Italy; \\ licia.bordi@inmi.it (L.B.); eleonora.lalle@inmi.it (E.L.); giuseppe.ippolito@inmi.it (G.I.); \\ maria.capobianchi@inmi.it (M.R.C.); concetta.castilletti@inmi.it (C.C.) \\ * Correspondence: giulia.matusali@inmi.it (G.M.); francesca.colavita@inmi.it (F.C.)
}

Received: 31 January 2019; Accepted: 17 February 2019; Published: 20 February 2019

\begin{abstract}
Chikungunya virus (CHIKV) is a re-emerging mosquito-borne virus that displays a large cell and organ tropism, and causes a broad range of clinical symptoms in humans. It is maintained in nature through both urban and sylvatic cycles, involving mosquito vectors and human or vertebrate animal hosts. Although CHIKV was first isolated in 1953, its pathogenesis was only more extensively studied after its re-emergence in 2004. The unexpected spread of CHIKV to novel tropical and non-tropical areas, in some instances driven by newly competent vectors, evidenced the vulnerability of new territories to this infectious agent and its associated diseases. The comprehension of the exact CHIKV target cells and organs, mechanisms of pathogenesis, and spectrum of both competitive vectors and animal hosts is pivotal for the design of effective therapeutic strategies, vector control measures, and eradication actions.
\end{abstract}

Keywords: chikungunya virus; viral tropism; arthropod vectors; animal hosts; pathogenesis; vertical transmission

\section{Introduction}

Chikungunya virus (CHIKV), a mosquito-borne alphavirus of the Togaviridae family, has caused over 70 epidemics between 1952 and 2018. It was first identified in 1952 in present day Tanzania (East Africa), and was isolated from infected patients' sera, and from Aedes and Culex spp. mosquitoes in 1953 [1]. In the late 1950s, CHIKV was described in Uganda, the sub-Saharan region, and in Central and Southern Africa [2]. Based on the phylogenetic analysis of the CHIKV sequences from these early African outbreaks, they were grouped under the East-, Central-, and South-African lineage (ECSA) [3].

A second lineage, known as West African (WA), was retrospectively identified in mosquitoes captured in Senegal [3]. Then, the virus is thought to have moved from Africa to Asia, where CHIKV outbreaks were initially confused with dengue epidemics. Genetic analyses of CHIKV isolated from 1958 to 1973 in Asia placed them in a distinct group called the Asian lineage [3,4]. More recently (2004), a phylogenetic group, the Indian Ocean sub Lineage (IOL), originated from an ECSA clade causing, among others, a large epidemic in Réunion Island in 2005 [5].

Cases of CHIKV (IOL lineage) have been described in Europe since 2007, when an outbreak was reported in northeastern Italy, with a total of 217 cases, and the presumed index case coming back from India [6]. Since then, autochthonous cases of CHIKV fever have occurred in France, Croatia, Spain, and Italy.

In the Pacific region, CHIKV (Asian lineage) was first detected in early 2011 in New Caledonia, and later traveled to other Pacific countries, including Micronesia and French Polynesia $[7,8]$.

In the Western Hemisphere, Asian CHIKV was initially identified in the Caribbean, precisely in Saint Martin Island, at the end of 2013, and from there it spread towards Central, North, and South 
America. Notably, the strains circulating in Brazil in 2014 were closely related to the ECSA isolates detected in Angola [8,9].

The most recent CHIKV outbreak was reported in Sudan, affecting seven states, with a total of 13,978 cases of chikungunya, $95 \%$ of which were from the Kassala State [10,11] (see [12] for a more extensive review on CHIKV epidemics).

\section{Invertebrate and Vertebrate Animal Hosts}

\subsection{Invetebrate Vectors}

Mosquitoes are the best-known vector of human diseases, and account for the vast majority of CHIKV transmission to humans through the urban transmission cycle (i.e., viral cycling between domestic mosquitoes and humans), as well as for the maintenance of the virus, during interepidemic periods, via the sylvatic transmission cycle (i.e., viral cycling between vectors and wild animals).

During the urban cycle, the insect species responsible for human infections are Aedes (Ae) aegypti and, most recently, Ae albopictus [13].

Nowadays, Ae aegypti remains the main vector for the urban cycle in Africa, the Americas, and Asia, and Ae albopictus is responsible for the large epidemic in the Indian Ocean Islands and for human cases in Europe, where it is the only vector present. A third species-Ae Hensilli-was indicated as the putative vector involved in the outbreak occurring in Micronesia in 2013 [14].

The vector competence of Ae albopictus, experimentally assessed in 1976 [15], was clearly demonstrated during the outbreak in the Indian Ocean region. During this epidemic, the absence of Ae aegypti on Reunion Island was the first clue suggesting the involvement of another vector, and on the basis of CHIKV-positive mosquito pools and competence testing, Ae albopictus was designated as being responsible for viral transmission, leading to the large amount of infected individuals [13]. Phylogenetic studies were carried out and a single mutation in the envelope viral gene E1 of an ECSA strain (alanine to valine at position 226, A226V E1) was considered responsible for the increased fitness of CHIKV in Ae albopictus and the consequent acquisition of a more effective vector competence. This mutation promoted viral replication and transmission by this highly anthropophilic mosquito [16,17], and allowed for the substantial geographic expansion of CHIKV throughout sub-Saharan Africa and Southeast Asia, and into Europe [18].

It is noteworthy that CHIKV isolated from some of the European autochthonous cases lacked the A226V substitution in E1 [19-21], indicating that other factors or mutations can determine the virus adaptation to Ae albopictus. Indeed, substitutions in the E2 and E3 genes have also been involved in the process [22,23]. These mutations are suggested to enhance the infection in the mosquito midgut, probably altering the entry process at the fusion step in the endosome [23,24].

The sylvatic transmission cycle, of known relevance in the maintenance of the virus in interepidemic periods in Africa, involves a wider range of mosquito species, including Ae aegypti, Ae africanus, Ae luteocephalus, Ae furcifer, and Ae taylori [25-29].

Moreover, several other mosquitoes have been found to be incidentally infected by CHIKV in Africa, including Culex spp., Anopheles spp., and Mansonia spp., nevertheless, their vector competence has not been demonstrated (for a full list of naturally infected African mosquitoes, see [30]).

Other arthropod species (i.e., non-mosquito-arthropods) do not seem to have a role in the vectorial transmission of $\mathrm{CHIKV}$, but the virus has been isolated in a very low percentage of ticks collected in Senegal and the Republic of Guinea [31,32].

Data from laboratory-based competence assays further enlarge the spectrum of CHIKV potential vectors. Results from nine studies demonstrated a full competence for CHIKV transmission of mosquitoes captured in Africa (Ae fulgens, Ae frucifer, Ae togoi, Ae triseriatus, Ae vittatus, Ae bromeliae, and Eretmapodites chrysogaster), New Zealand (Opifex fuscus), French Polynesia (Ae Polynesiensis); iv) Singapore (peridomestic Ae malayensis), Brazil (Haemagogus leucocelaenus and Ae Terrens), and Australia (Ae vigilax and Ae notoscriptus) [33-38]. Moreover, one study demonstrated the presence of CHIKV in 
the saliva of Culex gelidus mosquitoes after intrathoracic viral inoculation [39], while other researchers observed a low rate of CHIKV transmission for Ae koreicus, a mosquito new to Europe [40]. It is noteworthy that mosquito vectors display different degrees of vector competence for different CHIKV isolates, and the nsP3 viral protein seems to be a determinant of vector specificity [41].

CHIKV is horizontally transmitted to vectors during a blood meal on a viremic host with CHIKV viral titers ranging from $10^{3}-10^{5}$ plaque-forming units per $\mathrm{ml}(\mathrm{PFU} / \mathrm{mL})$ [42].

Once ingested, the virus reaches the midgut, where it penetrates the epithelium, probably via clathrin-mediated endocytosis [43], and it replicates.

There are two mechanisms proposed for the dissemination of CHIKV from the midgut to secondary organs, as follows: (i) newly formed chikungunya virions accumulate at the level of the midgut basal lamina (BL), and pass to secondary organs thanks to collagenases mediated BL remodeling [44-46]; (ii) virions enter the tracheal cells' system surrounding the midgut and travel to secondary organs, a mechanism described for other arboviruses [47-49].

Three to seven days post infection, whether through the direct passage of the BL or the infection of the tracheal system, the virus spreads to distant anatomical districts (i.e., from the abdomen to the head), eventually reaching the salivary glands $[33,50]$.

CHIKV replicates and is stored in the acinar cells of the Aedes mosquito salivary glands, where it apparently does not cause a cytopathic effect [51-54].

CHIKV infection of the fat bodies of the Aedes species, described for other arboviruses (e.g., dengue virus 2 (DENV 2) and Zika virus (ZIKV)) [49,55], is currently undetermined. On the contrary, viral isolation from the legs and wings indicate the presence of CHIKV in these districts [56] (see Figure 1 for CHIKV mosquito tissue tropism).

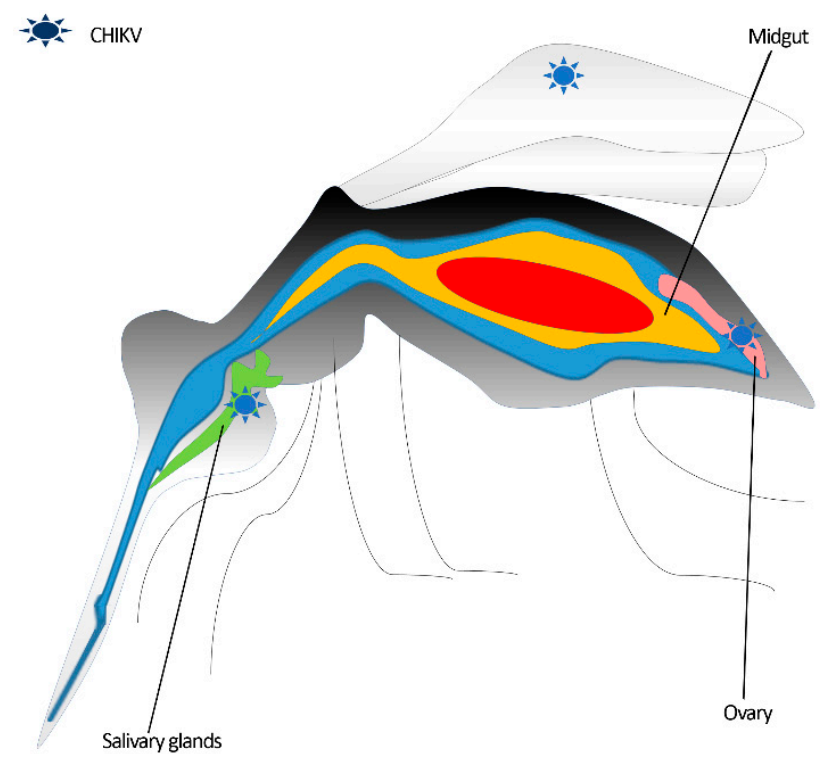

Figure 1. Sites of chikungunya virus replication in the Aedes mosquito vector.

Interestingly, the ovary is also infected by CHIKV, and replication at this site can determine the vertical transmission [57-61]. However, this transmission route seems to be rare [61], and some authors argue against the infectivity of the virus persisting in eggs [62]. The transovarial transmission of CHIKV through eggs potentially leads to virus survival in adverse environmental condition (eggs resist desiccation during the dry season) [63,64]. On the other hand, CHIKV seems to perturb the egg-laying pathway—resulting in a lower number of eggs—and survival rate of infected mosquitoes [57]. 


\subsection{Vertebrate Animal Hosts Spectrum}

Non-human vertebrate hosts have a prominent role in the maintenance of arboviruses in the enzootic cycle of infection. They constitute a viral reservoir from which the spillover to the human population may occur.

In Africa, during inter-epidemic periods, CHIKV is believed to be preserved via a sylvatic transmission cycle involving arboreal mosquitoes and wild primates.

This is in contrast to Asia, where the virus principally cycles between the two main vectors (i.e., Ae aegypti and Ae albopictus) and humans [13]. The role of vertebrate animals of new endemic regions (i.e., the Americas and the Pacific) and Europe in the amplification and survival of CHIKV has been poorly investigated to date. Indeed, the majority of studies evaluating the natural infection of non-human-vertebrate hosts have been realized in Africa (12 studies) (reviewed in [65] and [66-68]), and evidenced the prominent role of non-human primates (NHPs) in sylvatic transmission (Table 1).

In the early studies carried out in Senegal, CHIKV was isolated from non-human primates (NHPs) (i.e., Cercopithecus aethiops, Galago senegalensis, Papio papio, Erythrocebus patas, and Chlorocebus sabaeus), palm squirrel (Xerus erythropus), and bats of the Scotophillus species [27,31]. Seroprevalence studies enlarged the range of naturally infected mammals. Specific antibodies have been detected in the sera of several primates (Cercopithecus aethiops, Cercopithecus Ascanius, Cercopithecus mitis, Papio cynocephalus, Papio papio, Papio ursinus, Mandrillus sphinx, Galago senegalensis, Erythrocebus patas, Eulemur fulvus, and Macaca fascicularis), and with a low prevalence in one out of the 10 rodent species tested (ship rats, i.e., Rattus rattus) (reviewed in [65] and [66,67,69]).

Notably, neutralizing antibodies against CHIKV were measured in one forest buffalo (Syncerus caffer nanus) and one elephant (Loxodonta africana) from the Congo basin [70]. In contrast, negative results were obtained when testing domestic and farm animals, such as cats, dogs, cattle, goats, horses, sheep, pigs, and poultry $[69,71,72]$. To understand whether a sylvatic cycle can be established outside Africa, six studies investigated Asian NHPs' natural infection, founding CHIKV-specific antibodies in macaques (Macaca fascicularis and Macaca nemestrina) [73-78], and only one report was published on the infection and seroprevalence of CHIKV in American NHPs [79]. The American study showed low seroprevalence and antibody titers with negative RT-PCR results in 11 monkeys of five different species (Sapajus flavius, Sapajus robustu, Sapajus xanthosternos, Ateles marginatus, and Callithrix jacchusurban) in urban and peri-urban neotropical NHPs sampled in Brazil.

Given the results of non-human-vertebrates' natural infection, experimental investigations on host susceptibility to CHIKV were mostly conducted in NHPs and rodents, with the double aim of studying their potential role as a reservoir, and of establishing animal models of infection (reviewed in [65]). These studies show the higher susceptibility of infant or immunodeficient mice (as compared to adult mice), the infection of Rhesus and Cynomolgus macaques (i.e., Macaca mulatta and Macaca fascicularis), widely used experimental models, and of bats-a well-known reservoir involved in the spreading of emerging viruses.

Two trials of experimental viral inoculation, using two ECSA strains (one isolated from a patient in South Africa in the 1970s, the other from Comoros Island mosquitoes in 2005), have been recently performed to identify potentially competent hosts among domestic and wild animals common to North America [80,81]. The authors tested nine avian, twelve mammalian, three amphibian, and seven reptilian species in order to assess the onset of viremia and seroconversion upon CHIKV infection. The animals with detectable CHIKV viremia were some mammals (i.e., hamsters, C57BL/ 6 mice, and big brown bats), amphibians (Leopard frog and Texas toad), and reptiles (Ball python, Burmese python, Garter snake, Green iguana, Red-eared slider), and seroconversion occurred in all of the viremic reptiles, in Texas toads, and in bats. Moreover, a neutralizing antibody titer was measured in some of the non-viremic species, including domestic/farm/wild mammals (dog, pig, horse, calf, goat, armadillo, and raccoon), and a small proportion of birds. None of the tested animals developed clinical signs [81]. 
Table 1. Reported natural vertebrate animal hosts of the chikungunya virus. NHPs-non-human primates.

\begin{tabular}{|c|c|c|c|c|}
\hline \multirow{2}{*}{ World Region } & Species & Common Name & Method of Detection & References \\
\hline & \multicolumn{4}{|c|}{ NHPs: } \\
\hline \multirow{10}{*}{ Africa } & Cercopithecus aethiops & Vervet monkey & $\begin{array}{c}\text { Isolation and specific } \\
\text { antibodies }\end{array}$ & {$[27,28,31]$} \\
\hline & Cercopithecus mitis & Blue monkey & Specific antibodies & [67] \\
\hline & Cercopithecus ascanius & Red tailed monkey & Specific antibodies & {$[67,71]$} \\
\hline & Galago senegalensis & Senegal bushbaby & $\begin{array}{l}\text { Isolation and specific } \\
\text { antibodies }\end{array}$ & {$[27,31]$} \\
\hline & Papio papio & Guinea baboon & $\begin{array}{c}\text { Isolation and specific } \\
\text { antibodies }\end{array}$ & {$[27,66]$} \\
\hline & Papio cynocephalus & Yellow baboon & Specific antibodies & [67] \\
\hline & Papio ursinus & Cape baboon & Specific antibodies & {$[28,82]$} \\
\hline & Erythrocebus patas & Patas monkey & $\begin{array}{l}\text { Isolation and specific } \\
\text { antibodies }\end{array}$ & {$[27,66]$} \\
\hline & Chlorocebus sabaeus & $\begin{array}{c}\text { African green } \\
\text { monkey }\end{array}$ & $\begin{array}{c}\text { Isolation and specific } \\
\text { antibodies }\end{array}$ & {$[27,66]$} \\
\hline & Mandrillus sphinx & Mandrill & Specific antibodies & [70] \\
\hline Indian Ocean & Eulemur fulvus & Brown lemur & Specific antibodies & [69] \\
\hline $\begin{array}{c}\text { Indian Ocean and } \\
\text { Asia }\end{array}$ & Macaca fascicularis & $\begin{array}{l}\text { Crab eating } \\
\text { macaque }\end{array}$ & $\begin{array}{c}\text { Isolation and specific } \\
\text { antibodies }\end{array}$ & {$[74,77,78]$} \\
\hline Asia & Macaca nemestrina & Pig tailed macaque & Specific antibodies & [75] \\
\hline \multirow{6}{*}{ South America } & Ateles marginatus & Spider monkey & Specific antibodies & [79] \\
\hline & Callithrix jacchus & $\begin{array}{l}\text { Common } \\
\text { marmoset }\end{array}$ & Specific antibodies & [79] \\
\hline & Sapajus xanthosternos & $\begin{array}{c}\text { Golden-bellied } \\
\text { capuchin }\end{array}$ & Specific antibodies & [79] \\
\hline & Sapajus robustu & Crested capuchin & Specific antibodies & [79] \\
\hline & Sapajus flavius & Capuchin monkey & Specific antibodies & [79] \\
\hline & \multicolumn{4}{|c|}{ Mammals: } \\
\hline \multirow{5}{*}{ Africa } & Xerus erythropus & Palm squirrel & Isolation & [31] \\
\hline & Rattus rattus & Ship rat & Specific antibodies & [69] \\
\hline & Scotophillus species & Bat & Isolation & [31] \\
\hline & Syncerus caffer nanus & Buffalo & Specific antibodies & [70] \\
\hline & Loxodonta africana & Elephant & Specific antibodies & [70] \\
\hline
\end{tabular}

The investigations described suggest that, together with NHPs, some bats and rodents, as well as ectothermic animals, could serve as virus-amplifying hosts, while lessening the likelihood that numerous birds and non-primate mammals are competent reservoirs for CHIKV.

\section{CHIKV Cellular Receptors}

Viral tropism is defined as the capacity of a virus to infect specific cells, tissues, and species. It depends on both viral and cellular characteristics-with the presence of the cognate receptors for viral attachment molecules being of undeniable importance [83]. The CHIKV protein that facilitates cell binding is the E2 glycoprotein, while the related cellular receptor/s crucial for CHIKV entry 
has/have yet to be recognized [83]. Given the large tropism of CHIKV, its putative receptor/s is likely ubiquitously expressed among species and cell types [83].

The first molecule indicated as a CHIKV receptor in 2012 was Prohibitin 1 (PHB1), a multifunctional membrane protein expressed by numerous cell types [84]. In microglial cells, PHB1 was shown to co-immunoprecipitate with the CHIKV E2 protein, and the number of infected cells was significantly lowered when using anti-PHB1 blocking antibodies (a reduction of $20 \%$ to $40 \%$ compared with the untreated control) or upon PHB1 silencing (reduction of approximately $30 \%$ ). In the presence of blocking antibodies, the viral production was also significantly reduced [84]. The same group later confirmed the role of PHB1 in viral entry by pre-incubating HEK-293T cells with flavaglines (prohubitin ligands) before CHIKV infection. This pre-treatment reduced both the percentage of infected cells (20\% to $40 \%$ reduction) and the viral production (approximately $40 \%$ reduction) [85]. In 2018, Michael Diamond and colleagues, through a genome-wide screening for the cellular factors required for CHIKV entry, identified the cell adhesion molecule Mxra8. They demonstrated that blocking this molecule prior to CHIKV infection significantly reduced the number of human primary synovial fibroblasts (50\% reduction .ca), skeletal muscle cells ( $70 \%$ reduction .ca), osteoblasts $(70 \%$ reduction .ca), and chondrocytes (70\% reduction .ca) [86]. In a mouse model of in vivo CHIKV infection, the administration of the Mxr8a-Fc protein or blocking antibodies reduced both foot swelling and CHIKV infection with a differential efficiency, based on treatment kinetics [86]. Nevertheless, the lack of Mxra8 on the membranes of some CHIKV target cells (e.g., keratinocytes) indicates that this factor can be dispensable.

Two other molecules, T-cell immunoglobulin and mucin domain-1 (TIM-1), recently involved in ZIKV entry, and Glycosaminoglycans (GAGs), important for the efficient infection of alphaviruses (i.e., Eastern equine encephalitis virus (EEEV) and Venezuelan equine encephalitis virus (VEEV)), have been implicated in CHIKV attachment (reviewed in [83]) to human cells, while HSC70 and ATP synthase beta subunit have been suggested as CHIKV binding factors in mosquito cells $[87,88]$.

Overall, a plethora of cell membrane molecules have been indicated as putative CHIKV binding/entry factors, but no definitive identification has been established.

\section{Human Infection}

Following an infected mosquito bite, CHIKV is introduced into the human skin and into the bloodstream, causing high viremia, and when it reaches the target organs, it gives rise to pathological signs. Infection in humans usually manifests as fever, myalgia, and arthralgia, and in a small percentage of individuals, it gives rise to a range of so called "atypical signs" (defined as symptoms other than fever, myalgia, and arthralgia). The virus also replicates in lymphoid organs either before (axillary lymph nodes) and/or after the passage in the blood stream (lymph nodes and spleen). Moreover, non-arthropod-borne routes of transmission have been described (vertical transmission) or suspected (sexual transmission).

\subsection{Stages and Clinical Signs of Chikungunya Infection}

One major challenge for clinicians, nowadays, is to differentiate the clinical signs of chikungunya from those of Zika and dengue fever, especially when these viruses are co-circulating. Unlike ZIKV and DENV, whose infections are asymptomatic in about $62 \%$ and $75 \%$ of individuals, respectively [89,90], CHIKV causes symptoms in a high majority $(72 \%$ to $95 \%)$ of infected people $[91,92]$. CHIKV infects humans through the bite of Aedes spp. mosquito vectors, and causes the chikungunya virus disease (CHIKD), characterized, in the acute phase, by an abrupt onset of febrile illness ( $>39^{\circ} \mathrm{C}$ in $92 \%$ of patients), frequently accompanied by joint pain (arthralgia) (87\% of patients) [93].

Other common signs and symptoms include headache; fatigue; muscle pain (myalgia); distal joint swelling; cutaneous manifestations, such as macular or maculopapular rash; and gastrointestinal tract affections, such as nausea, vomiting, and abdominal pain [93,94]. Less frequently, ocular manifestations can occur, and range from photophobia to retro-orbital pain and conjunctivitis [95]. 
Chikungunya chronic disease is characterized by the persistence or relapse of joint pain, which was first reported in 1979 [96], and has been extensively described during recent/previous epidemics [97]. Joint pain may present for several weeks to months, and may mimic rheumatoid arthritis.

Rodriguez-Morales and coworkers systematically reviewed the data on post-chikungunya infection with chronic inflammatory arthritis in reports published from 2007 to 2015, and calculated that among the 5702 patients who were followed-up for more than 18 months, the pooled prevalence of chronic inflammatory rheumatism (CIR) associated to CHIKV infection was $40.2 \%$ [98].

A growing number of atypical signs and symptoms have been described during the last outbreaks. These include both mild and severe syndromes affecting several organs.

Economopoulou and colleagues reported that during the large 2005-2006 CHIKV outbreak on the Reunion Island, the proportion of atypical cases (defined as patients with laboratory confirmed CHIKV infection and symptoms other than fever and arthralgia) was $0.3 \% ; 36 \%$ of these atypical cases presented as severe cases, with a mortality of $29 \%$ (an overall case-fatality rate of $10.7 \%$ ) [99].

Cohort studies and case reports showed that the incidence rate of atypical, severe, and fatal cases increases with age in patients over 65 years old [99], and the presence of underlying medical conditions (i.e., preexisting respiratory or cardiovascular diseases and hypertension) is correlated to the occurrence of severe manifestations [100-102].

Unusual manifestations of chikungunya infection comprise cardiovascular, renal, cutaneous, ocular, hepatic, and respiratory syndromes [103-106].

Among the severe forms of CHIKD, it is important to mention the neurological complications (approximately $0.1 \%$ of CHIKV infection develops neurological disorders), most commonly encephalitis and encephalopathy, prompted the investigation of CHIKV tropism for the central nervous system (CNS) [107]. Acute flaccid paralysis and meningoencephalitis have also been described [99,108,109]. Moreover, Guillain-Barré syndrome (GBS), an acute inflammatory demyelinating polyneuropathy that usually occurs after infection by a variety of agents, including arboviruses, has been associated to CHIKV infection [107,110-112]. The tropism of CHIKV in the nervous system will be further detailed in Section 4.3.3.

The extensive array of clinical signs described during the acute and chronic phases of infection suggests a broad tissue tropism.

\subsection{Host Pathogen Interaction}

Upon infection, CHIKV, like other alphaviruses, strongly induces Type I interferons (IFN-I; IFN $\alpha$ and IFN $\beta$ ) production [113], and the effect of these cytokines in controlling CHIKV replication has been extensively investigated.

IFN-I and IFN stimulated genes are key factors of the innate antiviral immunity [114], and the role of IFN-I response in the context of CHIKV infection is evidenced by the full susceptibility to severe CHIKV infection of IFN-type-I receptors deficient (IFNAR -/-), in contrast to adult wild-type (wt) mice [115]. In vitro, CHIKV does not directly stimulate IFN-I production in immune cells. In contrast, infected non-hematopoietic cells (fibroblasts) sense viral RNA in a Cardif-dependent manner, and participate in the control of infection through the production of IFN-I [115].

In wt mice, upon intradermal inoculation, the viral replication was controlled by the action of IFN-I derived from fibroblasts, and the peak of IFN correlated with the decline in the CHIKV load. This prompt inhibition avoided CHIKV dissemination [115].

In infected patients and NHPs, the viral load in blood positively correlates with IFN- $\alpha$ production $[115,116]$, but the IFN- $\alpha$ burden is nevertheless not sufficient to halt the spread to target organs. This can be in part due to the counteraction of CHIKV proteins. Indeed, the viral nonstructural protein 2 (nsP2) has been shown to inhibit IFN stimulated JAK-STAT signaling [117], and the nonstructural protein 1 (nsP1) contrast viral restriction mediated by the IFN stimulated gene product BST-2/Tetherin [118]. Whether IFN-type-I overproduction may result in the exacerbation of clinical symptoms, as suggested in a case report [119], should be further investigated. 
Another mechanism of evasion from the immune control is mediated through the mobilization of the apoptotic machinery. Apoptosis is a defense mechanism to limit virus production and spread [120], but in vitro experiments demonstrated that CHIKV is able to hide in apoptotic blebs and infect bystander cells [121].

Viral replication is also accompanied by upregulated levels of inflammatory cytokines (such as IL-6, MCP1 (CCL2), IP-10 (CXCL10), MIG (CXCL9), IL1 $\beta$, and tumor necrosis factor (TNF $\alpha$ )) in the plasma of acutely infected CHIKV patients and NHPs [116,122-127]. Notably, IL-6, IL-1b, and $\mathrm{TNF} \alpha$ are pyrogenic cytokines contributing to fever [128], and are implicated in persistence and tissue destruction during arthralgia $[122,128,129]$. IL-6 is also a marker of poor prognosis, together with IL1 $\beta$ and RANTES [128].

A plethora of other cytokines/chemokines have been indicated as forming a generic acute CHIKV signature in a meta-analysis conducted in all patient cohorts from all around the world [130]; these include pro-inflammatory, anti-inflammatory, chemoattractant, and growth factors [130].

Another factor involved in the modulation of CHIKV pathogenesis is the interferon regulatory factor 1 (IRF-1), which in an IFN-independent manner, restricts CHIKV replication in muscle cells and contrasts the infiltration of neutrophils and eosinophils in the joint tissues of mice [131].

Monocytes/macrophages also have a role in CHIKV pathogenesis, both secreting inflammatory mediators, migrating to distal districts, and being the site of acute and persistent infection, as more extensively described next in this review (see Sections 4.3.1, 4.3.2, and 4.3.4).

Natural killer (NK) cells showed activated profiles during acute CHIKV [132], and NK cells' infiltration in the synovial tissue is suggested to participate in the pathogenesis of CHIKV-driven arthralgia [129].

Adaptive immunity is mediated by $\mathrm{B}$ and $\mathrm{T}$ cells. CHIKV induces a robust humoral response leading to the production of anti-CHIKV IgM and IgG [133]. The importance of the antibody response was corroborated by passive immunization investigations and vaccine studies (see Section 4.4). The importance of $\mathrm{T}$ and $\mathrm{B}$ cells has also been demonstrated in Rag1 knockout mice (which lack $\mathrm{T}$ and B cells), as these animals develop higher viral levels and disease severity compared with wt mice [134]. CD4+T cells are also involved in inflammation and the development of joint swelling [134,135]. $\mathrm{CD} 8+\mathrm{T}$ cells are strongly induced by vaccination in animal models, leading to an efficient cellular cytotoxic immune response (together with humoral immunity) $[136,137]$. Interestingly, age-related vulnerability as a result of reduced IFN-I, and T and B cell immunity has been demonstrated in NHP models [138].

The role of immune mediators at specific sites of replication will be further reviewed in the next sections.

\subsection{Cellular and Tissue Tropism in Human Infections}

\subsubsection{Infection of Skin and Blood Cells}

In human skin, the first human organs supporting viral replication upon a mosquito bite, the dermal fibroblasts, constitute the main site of viral amplification, as demonstrated in vitro [139-141], in mice models (IFN-type-I receptors deficient or neonates animals), and by the detection of viral antigens in a skin biopsy from a neonatal fatal case [142]. In these cells, CHIKV infection determines a strong antiviral IFN-type-I (IFN-I) response, alongside the production of pro-inflammatory cytokines. The induction of many antiviral genes (e.g., viral sensors, IFN-I receptors, and IFN stimulated genes (ISGs)) is however contrasted by components of Aedes mosquito saliva, thus favoring viral replication [141].

The same pro-viral effect of the mosquito salivary glands' extract was described upon in vitro infection of skin keratinocyte with an ECSA strain [143]. Contrasting results were obtained by another research group, who used IOL CHIKV strains encoding GFP or mCherry reporter genes to infect keratinocytes [144]. In their experimental conditions, the viral early steps of replication (binding 
and entry) were completed, while non-structural proteins and genomic RNA were poorly expressed, probably because of an IFN type I, II, and III mediated restriction. Notably, viral infection resulted in a transient induction of type I and II IFN genes, and a continuing increase of IFN-III mRNA (IFN type III being a cytokine preferentially expressed by epithelial cells). The susceptibility of primary human keratinocytes to CHIKV was recently confirmed by Zhang et al. [86], where the virus entered the cells in a Mxra8 independent manner.

In mice, the infection of keratinocytes was observed in interferon response factor 3 and 7 deficient (IRF3-/IRF7-), but not in wt animals [145]. As IRF-3 and -7 are regulatorx of type-I and -III IFNs [146,147], this mouse model supports a role for these antiviral pathways in CHIKV restriction.

Along with the dermal fibroblasts and keratinocytes, melanocytes are also permissive for CHIKV [148], while the infection of dermal macrophages is only assumed by the susceptibility of the blood derived and resident macrophages of other tissues (see Figure 2 for skin tropism).

The route from the skin to other anatomical districts has been characterized in NHP models, where CHIKV travels from the site of infection (i.e., the skin) into the draining axillary lymph nodes, and then causes viremia [116].

Viral replication in human blood was first suggested by strong viremia (the blood viral load can reach up to $10^{9} \mathrm{RNA}$ copies/ml) [149], but one pioneering study showed that the only in vitro infected lymphoid cells producing viral particles were primary monocyte-derived-macrophages [140]. Since then, CHIKV tropism for blood cells has been more extensively studied, and the active infection of human blood monocytes and, to a lesser extent, of B lymphocytes and plasmacytoid dendritic cells (pDCs), was demonstrated in peripheral blood mononuclear cells (PBMCs) derived from acutely infected patients, and upon in vitro infection $[124,150,151]$. Viral replication was accompanied by upregulated levels of immune mediators (e.g., IFN $\alpha$, IL-6, MCP1 (CCL2), IP-10 (CXCL10), MIP-1 $\beta$ (CCL4), and IL1R $\alpha$, MIG (CXCL9), IL1 $\beta$, and TNF $\alpha$ ) [150] and high levels of inflammatory cytokines (such as IFN $\alpha$, IL-6, MCP1 (CCL2), IP-10 (CXCL10), MIG (CXCL9), IL1 $\beta$, and $\mathrm{TNF} \alpha$ ) in the plasma of acutely infected CHIKV patients was found to correlate with high viral titers or disease severity [122-127]. Similar findings in NHPs further validate these models of CHIKV infection/pathogenesis [116].

A

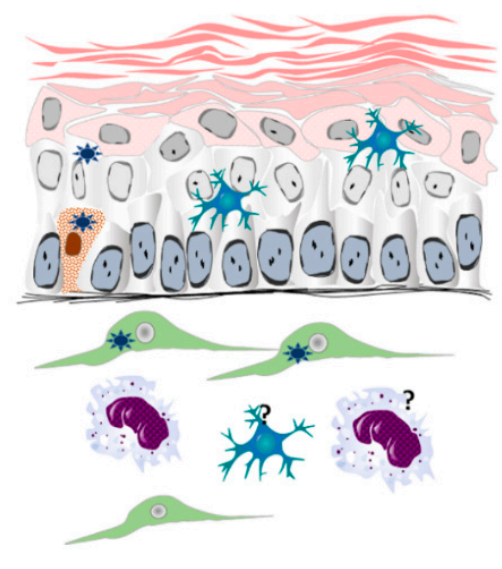

B

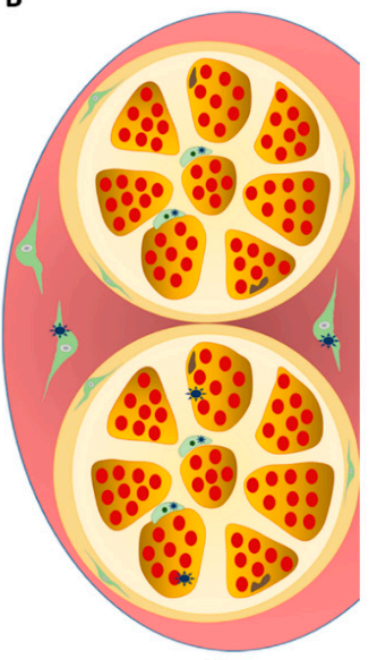

c

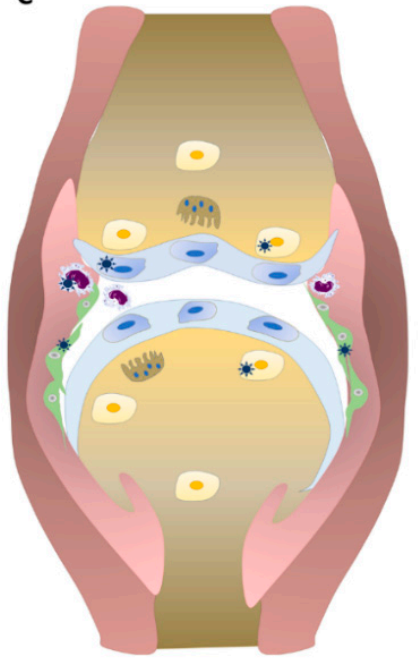

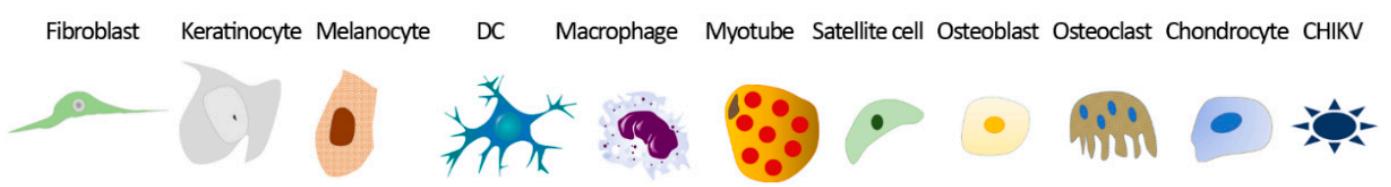

Figure 2. Examples of tissue and cell tropism of chikungunya virus. Chikungunya virus (CHIKV) infected cells in skin (A); skeletal muscle (B); joint and bone (C). DC-dendritic cell. 
Interestingly, viral replication dynamics in PBMCs experimentally infected with CHIKV and DENV resulted in a significant reduction of CHIKV progeny and a moderate enhancement of DENV production. Co-infection also led to higher levels of IL- 6 and TNF $\alpha$, implicated in the pathogenesis of the two arboviral diseases [152]. The effect of co-infections on CHIKV tropism and pathogenesis is ill-defined and should be further investigated both in humans and animal models.

Finally, CHIKV can also associate to red blood cells and platelets, a notion that should be considered for blood transfusion safety $[153,154]$.

\subsubsection{Infection of Muscle, Joint, and Bone}

During the acute and subacute phase, CHIKV reaches the muscle and joint compartments where it gives rise to the two main symptoms associated to this arbovirus-myalgia and arthralgia. During the Indian Ocean Islands outbreak, human muscle biopsies derived from two patients (one acutely infected and the other relapsing) were stained positive for CHIKV antigens in fusiform curved shape cells co-labelling with specific markers (i.e., laminin or neural cell adhesion molecule) of satellite cells [155]. The same study analyzed the myo-tropism in vitro, showing that, unlike satellite cells, differentiated myotubes were spared from infection. Nevertheless, primary human myoblasts were found to be permissive to CHIKV in a more recent study [156], and skeletal muscle fibroblasts were stained positive for viral antigens in a fatal neonatal case [142].

The ability of CHIKV to infect progenitor cells and to induce skeletal muscle necrosis may explain the CHIKV-induced myopathies, and implicate the muscle as a site of viral persistence.

The other distinctive CHIKV clinical syndrome is arthralgia, which is generally of symmetric type, with the distal synovial joints more commonly affected than the proximal [129].

CHIKV RNA and proteins have been identified in the synovial tissues and fluids during acute and persistent arthralgia $[129,149,155,157,158]$, and both synovial fibroblasts and macrophages are susceptible to CHIKV [86,129,142,159]. The histological analysis of a chronic patient's biopsy showed the active replication of CHIKV in joint macrophages' infiltration of activated NK cells and T cells (mainly CD4), and extensive apoptosis, while the analysis of the protein content of the synovial fluid revealed high levels of matrix metalloproteinase MMP2 (involved in tissue remodeling), CCL2, IL8 (monocytes and neutrophils chemo-attractive cytokines), and IL6 (multifunctional cytokine involved in inflammation) [129]. These data show that CHIKV-infected macrophages are a preferential site of viral persistence, in which the active replication of the virus take place and contributes to chronic symptoms.

Together with joint inflammation, cartilage degradation also takes place in CHIKV infected individuals. In humans, the presence of elevated levels of cartilage bioproducts in urine (i.e., proline, hydroxyproline, and mucopolysaccarides) [160], and the low levels of the plasmatic of hepatocyte growth factor (HGF; hormone facilitating cartilage repairs) in chronic patients [122], are indicative of connective tissue alteration and cartilage damage. In mouse models of CHIKV-induced arthritis, the destruction of cartilage and the formation of large areas of collagenosis and fibrosis were observed [125,161,162]. A direct effect of CHIKV on cartilage is suggested by viral replication in human primary chondrocytes [86] and in CHIKV inoculated immunodeficient (IRF3/7 ${ }^{-/}$) mice [145].

Bone loss is another hallmark of CHIKV arthritis, and osteoblasts are a site of CHIKV replication and persistence [86,163-165]. Ex vivo infection of human osteoblasts induced the secretion of IL6 and receptor activator of nuclear factor-kB ligand (RANKL), and a concomitant decrease in the osteoproteogerin (OPG) content in culture supernatants. This perturbation in the RANKL/OPG ratio has been evidenced in infected murine joints and in patients' sera [165]. The dysregulation in the RANKL/OPG ratio in CHIKV-infected joints, and the upregulation of monocyte chemoattractant proteins observed in mice joints (CCL2, CCL7, and CCL8) and in the serum of CHIKV patients (CCL2) $[122,123,129,165]$ favors an osteoclastogenic and chemo-attractive microenvironment. This was confirmed by the local infiltration of monocytes in CHIKV-infected animals $[125,166,167]$, and by the ability of supernatants of CHIKV infected synovial fibroblasts to induce migration and differentiation into the osteoclast-like cells of primary human monocytes [159]. Importantly, the inhibition of 
monocytes/macrophages recruitment or macrophages depletion attenuated arthritis and joint swelling in mouse models [165,167], but resulted in prolonged viremia, suggesting that macrophages are also required for the clearance of the virus [167] (see Figure 2 for CHIKV tropism in muscle, joint, and bone).

\subsubsection{Infection of the Nervous System}

CHIKV is not considered to be a true neurotropic virus (i.e., able to invade the neural tissue and replicate in the neurons), however cases of neurological manifestations have been reported in the outbreaks that have occurred since the ones in Asia in the 1960s and 1970s [168-170]. Upon the re-emergence of CHIKV in the Indian Ocean in 2005, a growing number of cases of neurological complications (e.g., meningitis, encephalitis, febrile seizures, Guillain Barré syndrome, and acute flaccid paralysis) associated to this arboviral infection were recognized, and the tropism of this agent for the nervous system was better characterized $[107,169]$. In patients presenting with neurological disease, the virus was frequently evidenced in the cerebrospinal fluid (CSF) by viral isolation or by RT-PCR (systematically reviewed in [107]), while in the few brain autopsies analyzed for histopathological studies, the presence of CHIKV antigens was not evaluated [171]. As a consequence, the target cells of CHIKV in the human brain remain unknown. Nevertheless, the in vitro infection of human cells demonstrated the susceptibility of neuroblastoma cells (neural crest derived cells) [172,173], and of glial cells, such as astrocytes [174,175], and microglial cells [176,177] to CHIKV. The apoptosis observed in CHIKV infected neuroblastoma cells and astrocytes suggests a direct implication of viral infection in disease pathogenesis. In experimentally infected mice, the virus preferentially infects astrocytes, and, to a lesser extent, neurons, while the infection of oligodendrocytes was evidenced in vitro [178-180]. In NHPs, CHIKV RNA was detected in the brain during the acute phase, and was shown to persist in the CSF [166].

Finally, the endothelial brain cells of human and animal origin can, in some instances, produce CHIKV infective particles [140,181,182].

The mechanisms by which CHIKV affects the human nervous system remain ill defined. It is still unclear whether it acts directly by targeting neurons and glial cells, or indirectly by triggering immune mediated effects (i.e., through the upregulation of inflammatory and antiviral cytokines).

In the nervous system, the eye may be injured in CHIKV patients. Ocular diseases present mainly as retro-orbital pain or conjunctivitis at the time of CHIKV systemic illness, and predominantly as uveitis, retinitis, or optic neuritis in later phases and recurrences [107,183-186].

The presence of viral RNA in ocular fluid was reported three times [187-189], and in a laboratory screening of CHIKV infection of corneal donors, infectious viral particles and RNA were detected in the eye tissue from four donors [189]. The characterization of CHIKV positive cells in the human eye revealed the infection of fibroblasts of the corneal and scleral stroma, corneal endothelium, ciliary body, iris, and between ocular muscle fibers [189]. Based on these results, the risk of CHIKV iatrogenic transmission through corneal transplantation must be taken into account.

\subsubsection{Infection of other Target Organs}

The wide range of secondary organs targeted by CHIKV may explain the rare consequences of chikungunya infection, and the clinical manifestations observed in patients (i.e., renal, respiratory, hepatic, cardiac, and neural syndromes) [103,104].

A relevant model of infection showing viremia and clinical signs similar to those seen in humans was developed by Labadie and coworkers [166], who inoculated a CHIKV IOL isolate into 15 cynomolgus macaques (Macaca fascicularis). High titers of viral RNA were measured in lymphoid organs as well as in the liver, where viral antigens localized in macrophages, DCs, and endothelial cells. The acute phase was also characterized by strong mononuclear cells' infiltrations in the spleen and lymph nodes [166]. The spleen, liver, and heart have been found to be positive for CHIKV in another NHP model [190], and viral RNA has been detected in the liver of a human fatal case [191]. 
Moreover, in vitro and in vivo findings suggest that kidneys and lungs are also targeted by CHIKV $[140,177,190,192]$. Both human and animal derived kidney epithelial and lung epithelial and fibroblasts cell lines are indeed susceptible to CHIKV, and are widely used for viral assays $[140,177,192]$. Nevertheless, the exact target cells of CHIKV in human secondary target organs (e.g., the kidney, liver, heart, lungs, etc.) and its ability to persist in such anatomical sites remains unclear.

It is noteworthy that, when speaking of viral secondary sites of replication, viral RNA can, in some instances, be detected in body fluid specimens such as saliva and urine. In the saliva, CHIKV seems to originate from oral bleeding [193], while whether viral RNA in urine is derived from local renal replication is unknown [194,195]. During the Italian outbreak in 2017, we screened 1414 serum specimens for the presence of CHIKV RNA, and 196 of these resulted positive. For some viremic patients, body fluids other than serum became available for further diagnostic study, and viral RNA was detected in one saliva, one urine, and one cervico-vaginal fluid (CVF) specimen (unpublished data) (Table 2).

Table 2. Chikungunya virus (CHIKV) RNA detection in biological fluids in viremic patients during the Italian outbreak (2017).

\begin{tabular}{ccc}
\hline Specimen & Tested & Positive \\
\hline Saliva & 5 & 1 \\
Urine & 9 & 1 \\
Ocular swabs & 2 & 0 \\
CVF & 4 & 1 \\
\hline
\end{tabular}

CVF = Cervico-vaginal fluid.

\subsubsection{Target Organs upon Non-Arthropod-Borne Transmission}

Cases of mother to child CHIKV transmission have been reported, and a recent systematic review and meta-analysis evaluated the risk of this secondary route of viral spread [196]. Across the cohorts examined in this review, the overall risk for mother to child transmission was $15.5 \%$ (206/1331), with risk for symptomatic neonatal disease as 50.0\% among intrapartum, and $0 \%$ among antepartum/peripartum maternal infections. Symptomatic newborns develop a wide range of clinical signs, including fever; arthralgia; irritability; poor feeding; rashes; and, occasionally, multiple organ involvement, meningoencephalitis, and long term neurodevelopmental delays [196]. In a cohort study, delivery via caesarean section appeared to have no influence on the transmission risk, supporting the notion of the trans-placental transmission of CHIKV, rather than exposure in the birth canal [197]. Notably, three cases of early maternal-fetal transmission $(<16$ weeks' gestational age) occurred during the outbreak in Reunion Island, which reportedly described the presence of viral RNA in the amniotic fluid (three fetuses), in the placentas (two fetuses), and in the brains (two fetuses) of aborted fetuses [198]. In a cohort study from the same epidemics, CHIKV RNA was again detected in the amniotic fluid (4/23 samples) and placental tissue (19/462) [199], and a fatal Brazilian fetal case of the Zika virus and CHIKV co-infection presented with CHIV RNA in the placenta [200].

Some authors argue against the placental tropism of CHIKV, as the replicating virus has never been isolated from infected placental tissues; and human syncytiotrophoblastic cell lines are refractory to infection in vitro $[142,201]$.

Nowadays, the hypothesized mechanism of CHIKV vertical transmission is the passage of the virus from the maternal bloodstream through breaches in the placenta, a pathway supported by a study in an IFN-alpha-receptor knock-out mouse model [142]. However, recent research showed in vitro CHIKV replication in human fetal membranes (from the second trimester), but not in maternal-derived decidua or fetal-derived chorionic villi [202]. Further studies are undeniably necessary in order to dissect the mechanisms and to reveal the risk factors of CHIKV mother to child transmission.

Another non-arthropod-borne route under investigation is the sexually driven spreading. Indeed, since the discovery of ZIKV sexual transmission, great efforts have been made to understand whether 
other arboviruses are able to infect the genital tract, and whether they can be passed through sexual intercourse. CHIKV RNA was detected in the seminal fluid of one patient who was co-infected with DENV3. In this patient, the semen remained positive one month from the onset of symptoms [203].

To our knowledge, together with the detection of CHIKV RNA in the CVF, which we show in Table 2, these are the only reported cases of CHIKV detection in genital fluids, and the tropism of the virus for the genital tract, as well as its potential to be transmitted through male or female genital secretions, should be further investigated.

\subsection{Preventive and Therapeutic Strategies}

Despite the fact that CHIKV causes disease around the globe, with a significant impact on the quality of patients' life as well as the relevant economic burden, no specific anti-viral drugs or/and licensed vaccines are available, to date. Treatment is entirely symptomatic, and only palliative care can be administered (analgesics, antipyretics, non-steroidal anti-inflammatory drugs (NSAIDs), and systemic glucocorticoids in the case of severe and persistent joint pain) [204]. CHIKV infection may not always present specific manifestations, and it may co-exist with other infectious diseases, like dengue or Zika fever [205]. Thus, careful clinical management in the absence of laboratory confirmation is crucial. According to the WHO guidelines, paracetamol is the first-line analgesic treatment, and aspirin or other NSAIDs should be avoided, because of their adverse effects and the increased risk of bleeding manifestations in cases of DENV (co-)infection [206].

To find an effective treatment for CHIKV, numerous antivirals have been investigated. In vitro and in animal model studies showed that licensed antiviral compounds for other RNA viruses, such as Ribavirin, Favipiravir, IFN- $\alpha$, and Sofosbuvir, may have a positive effect in controlling CHIKV replication [8,207-210]. Chloroquine (CQ), a common antimalarial medicine, was widely used to treat rheumatoid arthritis-like symptoms, following CHIKV infection during the Reunion Island outbreak [204,211]. Although CQ inhibits CHIKV replication in vitro [212,213], it showed no or a moderate effect on CHIKV acute and chronic symptoms in humans [211,214], and in NHPs, it even determined enhanced CHIKV replication and delayed cellular and humoral response [214].

Immunotherapy using anti-CHIKV monoclonal antibodies represents a different approach for therapeutic and post-exposure interventions, and studies conducted on mice models evidenced good protection, even when administered at later time points after infection [208,215].

Because of the limited diversity between CHIKV strains, vaccine strategy represents the best preventive measure to limit the spread of infection and protect people from the disease. Despite the fact that none have been approved, several vaccine candidates have been investigated in preclinical and clinical studies. From the first vaccines prepared using the formalin-inactivated approach, various live-attenuated candidates have been developed and tested [216]. TSI-GSD-218 was the first live-attenuated CHIKV vaccine reported in trial, and was made using CHIK 181/clone 25 serially passed in cell cultured; it was shown to provide effective and lasting immunity, but in phase II, it caused mild arthralgia in $8 \%$ of the vaccinees [208]. Thereafter, the research moved towards other methodologies in order to ensure optimal safety and higher levels of protection and immunogenicity [208]. Examples are the CHIKV/IRES vaccine [217], and those preparations containing alphavirus chimeras [218] or modifications in the viral genome, such deletions [217] or codon alteration [219]. New promising candidates are the replication-deficient viral-like particles (VLP) vaccines (based on cDNA expression plasmid transfected into human cells, and containing CHIKV structural proteins), and the viral vectored vaccines (VVV), which use recombinant replication-deficient viruses as antigen delivery vectors (i.e., the measles virus (MV-CHIV) and adenovirus derived from a chimpanzee (ChAdOx)) [216]. The VRC-CHKVLP059-00-VP VLP vaccine entered a phase II trial in 2015; MV-CHIKV VVV completed a phase II trial with a good level safety and immunogenicity; the ChAdOx1-Chik vaccine is in a phase I trial, and the experimentation is ongoing [216].

In waiting for the final licensed vaccines and drugs to be used especially in endemic areas and risk population, or in case of epidemics, a great contribution of public health value is recognized in 
vector-control tools (i.e., insecticides, larvicides, traps, and repellents for personal protection) and integrated alternative strategies, which are under evaluation, and mainly aim to suppress vector mosquito populations and avoid the risk of resistance to chemical interventions (i.e., sterile insect technique (SIT), release of insects with dominant lethality (RIDL), and Wolbachia-infected males) [220].

\section{Conclusions}

Before 2004, CHIKV caused small outbreaks in confined regions within Africa and Asia. Then, the virus started to cause large outbreaks, and spread to novel areas, including Europe, the Americas, and the Pacific Islands. Notably, no specific antiviral treatment is available yet, and the case management of CHIKD patients is based on supportive care.

While early research studies are mainly focused on the identification of viral vectors and natural reservoirs, the understanding of the pathogenesis and the biology of the virus greatly improved since its re-emergence.

The clinical signs of CHIKD have been better characterized, and several syndromes have been newly associated to CHIKV infection.

The expansion to novel regions and the drastic increase of clinical cases prompted the scientific community to actively investigate the pathogenic and ecological aspect, including the tissue and cell tropism of the virus, the immune response of the host, the mechanisms of viral persistence, the competence of arthropod vectors, the spectrum of other potential animal hosts, and the urban and sylvatic cycle of CHIKV.

Studies on the viral tropism demonstrated preferential replication in fibroblasts and monocytes/macrophages, which, nevertheless, are not the only viral targets. Indeed, a number of other cells, including epithelial, endothelial, and muscular cells, are permissive to CHIKV, as established from in vitro studies and supported by ex vivo findings. Nevertheless, the exact cellular receptors for CHIKV need to be definitively established.

At the tissue level, CHIKV is amplified at the site of infection, the skin, and in the blood monocytes, which then reaches both the lymphoid and non-lymphoid organs, including the skeletal muscle and the synovial joints. At these sites, CHIKV may persist for several months, giving rise to chronic arthralgia, a hallmark of CHIKD.

The mechanisms leading to atypical diseases need to be further investigated, as it is the case of neurological manifestations, where it could be the result of a direct infection of the CNS or of the inflammatory pathways triggered by the virus.

Moreover, as CHIKV is often co-circulating with other arthropod-borne pathogens, it is of importance to consider co-infections (e.g., ZIKV, DENV, and Plasmodium falciparum) as risk factors potentially exacerbating the clinical outcome. However, more studies are required to create a consensus on the consequences of these events.

Global vigilance and vector control measures are needed, taking into account that a large range of mosquitoes are or may become competent for viral transmission. So, those actions specifically targeting the two main vectors (i.e., Ae aegypti and Ae albopictus), would not be sufficient, and could even favor the expansion and gain of competence of other species.

Finally, while NHPs are clearly involved in enzootic transmission in Africa, very little is known about the role of animals in the maintenance of the virus in sylvatic or peri-urban cycles outside this continent. Attention should be paid to the possible establishment of natural reservoirs contrasting eradication measures.

Author Contributions: G.M. reviewed the literature, prepared figures, and wrote the paper; F.C. helped in the bibliography search and performed the diagnostic tests; L.B., E.L., and C.C. performed the diagnostic tests; all of the authors provided critical feedback and helped shape the manuscript; G.I., M.R.C., and C.C. acquired the funding.

Acknowledgments: This work was supported by funds from the Italian Ministry of Health (Ricerca Corrente "Linea 1" and Ricerca Finalizzata) and the European Union's Horizon 2020 research and innovation program, 
European Virus Archive (EVAg, grant no. 653316). The authors thank Séverine Mazaud-Guittot for help with the graphics and Sadia Khan for English editing.

Conflicts of Interest: The authors declare no conflict of interest.

\section{References}

1. Ross, R.W. The Newala epidemic. III. The virus: Isolation, pathogenic properties and relationship to the epidemic. J. Hyg. 1956, 54, 177-191. [CrossRef] [PubMed]

2. Weinbren, M.P. The occurrence of Chikungunya virus in Uganda. II. In man on the Entebbe peninsula. Trans. R. Soc. Trop. Med. Hyg. 1958, 52, 258-259. [PubMed]

3. Powers, A.M.; Brault, A.C.; Tesh, R.B.; Weaver, S.C. Re-emergence of chikungunya and o'nyong-nyong viruses: Evidence for distinct geographical lineages and distant evolutionary relationships. J. Gen. Virol. 2000, 81, 471-479. [CrossRef] [PubMed]

4. Volk, S.M.; Chen, R.; Tsetsarkin, K.A.; Adams, A.P.; Garcia, T.I.; Sall, A.A.; Nasar, F.; Schuh, A.J.; Holmes, E.C.; Higgs, S.; et al. Genome-Scale Phylogenetic Analyses of Chikungunya Virus Reveal Independent Emergences of Recent Epidemics and Various Evolutionary Rates. J. Virol. 2010, 84, 6497-6504. [CrossRef] [PubMed]

5. Schuffenecker, I.; Iteman, I.; Michault, A.; Murri, S.; Frangeul, L.; Vaney, M.-C.; Lavenir, R.; Pardigon, N.; Reynes, J.-M.; Pettinelli, F.; et al. Genome Microevolution of Chikungunya Viruses Causing the Indian Ocean Outbreak. PLoS Med. 2006, 3, e263. [CrossRef] [PubMed]

6. Rezza, G.; Nicoletti, L.; Angelini, R.; Romi, R.; Finarelli, A.; Panning, M.; Cordioli, P.; Fortuna, C.; Boros, S.; Magurano, F.; et al. Infection with chikungunya virus in Italy: An outbreak in a temperate region. Lancet 2007, 370, 1840-1846. [CrossRef]

7. Aubry, M.; Teissier, A.; Roche, C.; Richard, V.; Yan, A.S.; Zisou, K.; Rouault, E.; Maria, V.; Lastère, S.; Cao-Lormeau, V.-M.; et al. Chikungunya Outbreak, French Polynesia, 2014. Emerg. Infect. Dis. 2015, 21, 724-726. [CrossRef] [PubMed]

8. Burt, F.J.; Chen, W.; Miner, J.J.; Lenschow, D.J.; Merits, A.; Schnettler, E.; Kohl, A.; Rudd, P.A.; Taylor, A.; Herrero, L.J.; et al. Chikungunya virus: An update on the biology and pathogenesis of this emerging pathogen. Lancet Infect. Dis. 2017, 17, e107-e117. [CrossRef]

9. Nunes, M.R.T.; Faria, N.R.; de Vasconcelos, J.M.; Golding, N.; Kraemer, M.U.; de Oliveira, L.F.; Azevedo, R.; da Silva Azevedo, R.D.S.; da Silva, D.E.A.; da Silva, E.V.P.; et al. Emergence and potential for spread of Chikungunya virus in Brazil. BMC Med. 2015, 13, 102. [CrossRef]

10. Mohamed, N.; Magzoub, M.; Mohamed, R.E.H.; Aleanizy, F.S.; Alqahtani, F.Y.; Nour, B.Y.M.; Alkarsany, M.M.S. Prevalence and identification of arthropod- transmitted viruses in Kassala state, Eastern Sudan. Libyan J. Med. 2019, 14, 1564511. [CrossRef]

11. WHO Chikungunya-Sudan Disease Outbreak News. Available online: https://www.who.int/csr/don/15october-2018-chikungunya-sudan/en/ (accessed on 19 February 2019).

12. Zeller, H.; Van Bortel, W.; Sudre, B. Chikungunya: Its history in Africa and Asia and its spread to new regions in 2013-2014. J. Infect. Dis. 2016, 214, S436-S440. [CrossRef] [PubMed]

13. Higgs, S.; Vanlandingham, D. Chikungunya Virus and Its Mosquito Vectors. Vector-Borne Zoonotic Dis. 2015, 15, 231-240. [CrossRef] [PubMed]

14. Savage, H.M.; Ledermann, J.P.; Yug, L.; Burkhalter, K.L.; Marfel, M.; Hancock, W.T. Incrimination of Aedes (Stegomyia) hensilli Farner as an epidemic vector of Chikungunya virus on Yap Island, Federated States of Micronesia, 2013. Am. J. Trop. Med. Hyg. 2015, 92, 429-436. [CrossRef] [PubMed]

15. Tesh, R.B.; Gubler, D.J.; Rosen, L. Variation among goegraphic strains of Aedes albopictus in susceptibility to infection with chikungunya virus. Am. J. Trop. Med. Hyg. 1976, 25, 326-335. [CrossRef] [PubMed]

16. Tsetsarkin, K.A.; Chen, R.; Sherman, M.B.; Weaver, S.C. Chikungunya virus: Evolution and genetic determinants of emergence. Curr. Opin. Virol. 2011, 1, 310-317. [CrossRef] [PubMed]

17. Tsetsarkin, K.A.; Vanlandingham, D.L.; McGee, C.E.; Higgs, S. A single mutation in chikungunya virus affects vector specificity and epidemic potential. PLoS Pathog. 2007, 3, e201. [CrossRef] [PubMed]

18. Thiberville, S.-D.; Moyen, N.; Dupuis-Maguiraga, L.; Nougairede, A.; Gould, E.A.; Roques, P.; de Lamballerie, X. Chikungunya fever: Epidemiology, clinical syndrome, pathogenesis and therapy. Antiviral Res. 2013, 99, 345-370. [CrossRef] 
19. Vega-Rua, A.; Zouache, K.; Caro, V.; Diancourt, L.; Delaunay, P.; Grandadam, M.; Failloux, A.-B. High Efficiency of Temperate Aedes albopictus to Transmit Chikungunya and Dengue Viruses in the Southeast of France. PLoS ONE 2013, 8, e59716. [CrossRef]

20. Grandadam, M.; Caro, V.; Plumet, S.; Thiberge, J.-M.; Souarès, Y.; Failloux, A.-B.; Tolou, H.J.; Budelot, M.; Cosserat, D.; Leparc-Goffart, I.; et al. Chikungunya Virus, Southeastern France. Emerg. Infect. Dis. 2011, 17, 910-913. [CrossRef]

21. Bordi, L.; Carletti, F.; Lalle, E.; Colavita, F.; Meschi, S.; Di Caro, A.; Nicastri, E.; Scognamiglio, P.; Vairo, F.; Di Lallo, D.; et al. Molecular characterization of autochthonous chikungunya cluster in latium region, Italy. Emerg. Infect. Dis. 2018, 24, 178-180. [CrossRef]

22. Tsetsarkin, K.A.; Weaver, S.C. Sequential Adaptive Mutations Enhance Efficient Vector Switching by Chikungunya Virus and Its Epidemic Emergence. PLoS Pathog. 2011, 7, e1002412. [CrossRef] [PubMed]

23. Tsetsarkin, K.A.; Chen, R.; Yun, R.; Rossi, S.L.; Plante, K.S.; Guerbois, M.; Forrester, N.; Perng, G.C.; Sreekumar, E.; Leal, G.; et al. Multi-peaked adaptive landscape for chikungunya virus evolution predicts continued fitness optimization in Aedes albopictus mosquitoes. Nat. Commun. 2014, 5, 4084. [CrossRef] [PubMed]

24. Arias-Goeta, C.; Mousson, L.; Rougeon, F.; Failloux, A.B. Dissemination and Transmission of the E1-226V Variant of Chikungunya Virus in Aedes albopictus Are Controlled at the Midgut Barrier Level. PLoS ONE 2013, 8, e57548. [CrossRef] [PubMed]

25. Jupp, P.G.; McIntosh, B.M. Aedes furcifer and other mosquitoes as vectors of chikungunya virus at Mica, northeastern Transvaal, South Africa. J. Am. Mosq. Control Assoc. 1990, 6, 415-420. [PubMed]

26. Jupp, P.G.; McIntosh, B.M.; Dos Santos, I.; DeMoor, P. Laboratory vector studies on six mosquito and one tick species with chikungunya virus. Trans. R. Soc. Trop. Med. Hyg. 1981, 75, 15-19. [CrossRef]

27. Diallo, M.; Thonnon, J.; Traore-lamizana, M.; Fontenille, D. Vectors of Chikungunya virus in Senegal: Current data and transmission cycles. Am. J. Trop. Med. Hyg. 1999, 60, 281-286. [CrossRef] [PubMed]

28. McIntosh, B.M.; Paterson, H.E.; McGillivray, G.; Desousa, J. Further studies on the chikungunya outbreak in Rhodesia. I. Mosquitoes, wild primates and birds in relation to the epidemic. Ann. Trop. Med. Parasitol. 1964, 58, 45-51. [CrossRef]

29. Weinbren, M.P.; Haddow, A.J.; Williams, M.C. The occurrence of Chikungunya virus in Uganda. I. Isolation from mosquitoes. Trans. R. Soc. Trop. Med. Hyg. 1958, 52, 253-257. [CrossRef]

30. Diallo, D.; Dia, I.; Diagne, C.T.; Gaye, A.; Diallo, M. Emergences of Chikungunya and Zika in Africa. In Chikungunya and Zika Viruses; Higgs, S., Vanlandingham, D.L., Powers, A.M., Eds.; Elsevier: Amsterdam, The Netherlands, 2018; pp. 87-133, ISBN 9780128118658.

31. Brès, P.; Camicas, J.L.; Cornet, M.; Robin, Y.; Taufflieb, R. Epidemiology of arbovirus diseases in Senegal. Bull. Soc. Pathol. Exot. Filiales 1969, 62, 253-259.

32. Konstantinov, O.K. Ticks of the Ixodidae family as reservoir of arboviruses in the Republic of Guinea. II. Arboviruses. Rev. Elev. Med. Vet. Pays Trop. 1990, 43, 15-22.

33. Coffey, L.L.; Failloux, A.B.; Weaver, S.C. Chikungunya virus-vector interactions. Viruses 2014, 6, 4628-4663. [CrossRef] [PubMed]

34. Mulwa, F.; Lutomiah, J.; Chepkorir, E.; Okello, S.; Eyase, F.; Tigoi, C.; Kahato, M.; Sang, R. Vector competence of Aedes bromeliae and Aedes vitattus mosquito populations from Kenya for chikungunya virus. PLoS Negl. Trop. Dis. 2018, 12, e0006746. [CrossRef] [PubMed]

35. Richard, V.; Paoaafaite, T.; Cao-Lormeau, V.-M. Vector Competence of Aedes aegypti and Aedes polynesiensis Populations from French Polynesia for Chikungunya Virus. PLoS Negl. Trop. Dis. 2016, 10, e0004694. [CrossRef] [PubMed]

36. Mendenhall, I.H.; Manuel, M.; Moorthy, M.; Lee, T.T.M.; Low, D.H.W.; Missé, D.; Gubler, D.J.; Ellis, B.R.; Ooi, E.E.; Pompon, J. Peridomestic Aedes malayensis and Aedes albopictus are capable vectors of arboviruses in cities. PLoS Negl. Trop. Dis. 2017, 11, 1-17. [CrossRef] [PubMed]

37. Lourenço-de-Oliveira, R.; Failloux, A.B. High risk for chikungunya virus to initiate an enzootic sylvatic cycle in the tropical Americas. PLoS Negl. Trop. Dis. 2017, 11, 1-11. [CrossRef] [PubMed]

38. van den Hurk, A.F.; Hall-Mendelin, S.; Pyke, A.T.; Smith, G.A.; Mackenzie, J.S. Vector Competence of Australian Mosquitoes for Chikungunya Virus. Vector-Borne Zoonotic Dis. 2010, 10, 489-495. [CrossRef] [PubMed] 
39. Sudeep, A.B.; Ghodke, Y.S.; George, R.P.; Ingale, V.S.; Dhaigude, S.D.; Gokhale, M.D. Vectorial capacity of Culex gelidus (Theobald) mosquitoes to certain viruses of public health importance in India. J. Vector Borne Dis. 2015, 52, 153-158. [PubMed]

40. Ciocchetta, S.; Prow, N.A.; Darbro, J.M.; Frentiu, F.D.; Savino, S.; Montarsi, F.; Capelli, G.; Aaskov, J.G.; Devine, G.J. The new European invader Aedes (Finlaya) koreicus: A potential vector of chikungunya virus. Pathog. Glob. Health 2018, 112, 107-114. [CrossRef]

41. Fros, J.J.; Geertsema, C.; Zouache, K.; Baggen, J.; Domeradzka, N.; Van Leeuwen, D.M.; Flipse, J.; Vlak, J.M.; Failloux, A.B.; Pijlman, G.P. Mosquito Rasputin interacts with chikungunya virus nsP3 and determines the infection rate in Aedes albopictus. Parasites Vectors 2015, 8, 1-15. [CrossRef]

42. Pesko, K.; Westbrook, C.J.; Mores, C.N.; Lounibos, L.P.; Reiskind, M.H. Effects of infectious virus dose and bloodmeal delivery method on susceptibility of Aedes aegypti and Aedes albopictus to chikungunya virus. J. Med. Entomol. 2009, 46, 395-399. [CrossRef]

43. Lee, R.C.H.; Hapuarachchi, H.C.; Chen, K.C.; Hussain, K.M.; Chen, H.; Low, S.L.; Ng, L.C.; Lin, R.; Ng, M.M.L.; Chu, J.J.H. Mosquito Cellular Factors and Functions in Mediating the Infectious entry of Chikungunya Virus. PLoS Negl. Trop. Dis. 2013, 7, e2050. [CrossRef] [PubMed]

44. Dong, S.; Balaraman, V.; Kantor, A.M.; Lin, J.; Grant, D.A.G.; Held, N.L.; Franz, A.W.E. Chikungunya virus dissemination from the midgut of Aedes aegypti is associated with temporal basal lamina degradation during bloodmeal digestion. PLoS Negl. Trop. Dis. 2017, 11, 1-26. [CrossRef] [PubMed]

45. Dong, S.; Kantor, A.M.; Lin, J.; Passarelli, A.L.; Clem, R.J.; Franz, A.W.E. Infection pattern and transmission potential of chikungunya virus in two New World laboratory-adapted Aedes aegypti strains. Sci. Rep. 2016, 6, 24729. [CrossRef]

46. Kantor, A.M.; Grant, D.G.; Balaraman, V.; White, T.A.; Franz, A.W.E. Ultrastructural analysis of chikungunya virus dissemination from the midgut of the yellow fever mosquito, aedes aegypti. Viruses 2018, 10, 571. [CrossRef] [PubMed]

47. Bowers, D.F.; Coleman, C.G.; Brown, D.T. Sindbis virus-associated pathology in Aedes albopictus (Diptera: Culicidae). J. Med. Entomol. 2003, 40, 698-705. [CrossRef] [PubMed]

48. Romoser, W.S.; Wasieloski, L.P.; Pushko, P.; Kondig, J.P.; Lerdthusnee, K.; Neira, M.; Ludwig, G.V. Evidence for arbovirus dissemination conduits from the mosquito (Diptera: Culicidae) midgut. J. Med. Entomol. 2004, 41, 467-475. [CrossRef]

49. Salazar, M.I.; Richardson, J.H.; Sánchez-Vargas, I.; Olson, K.E.; Beaty, B.J. Dengue virus type 2: Replication and tropisms in orally infected Aedes aegypti mosquitoes. BMC Microbiol. 2007, 7, 9. [CrossRef]

50. Ziegler, S.A.; Nuckols, J.; McGee, C.E.; Huang, Y.S.; Vanlandingham, D.L.; Tesh, R.B.; Higgs, S. In Vivo Imaging of Chikungunya Virus in Mice and Aedes Mosquitoes Using a Renilla Luciferase Clone. Vector-Borne Zoonotic Dis. 2011, 11, 1471-1477. [CrossRef]

51. Vega-Rúa, A.; Schmitt, C.; Bonne, I.; Locker, J.K.; Failloux, A.B. Chikungunya virus replication in salivary glands of the mosquito aedes albopictus. Viruses 2015, 7, 5902-5907. [CrossRef]

52. Tchankouo-Nguetcheu, S.; Bourguet, E.; Lenormand, P.; Rousselle, J.-C.; Namane, A.; Choumet, V. Infection by chikungunya virus modulates the expression of several proteins in Aedes aegypti salivary glands. Parasit. Vectors 2012, 5, 264. [CrossRef]

53. Le Coupanec, A.; Tchankouo-Nguetcheu, S.; Roux, P.; Khun, H.; Huerre, M.; Morales-Vargas, R.; Enguehard, M.; Lavillette, D.; Missé, D.; Choumet, V. Co-infection of mosquitoes with chikungunya and dengue viruses reveals modulation of the replication of both viruses in midguts and salivary glands of Aedes aegypti mosquitoes. Int. J. Mol. Sci. 2017, 18, 1708. [CrossRef] [PubMed]

54. Janzen, H.G.; Rhodes, A.J.; Doane, F.W. Chikungunya virus in salivary glands of Aedes aegypti (L.): An electron microscope study. Can. J. Microbiol. 1970, 16, 581-586. [CrossRef] [PubMed]

55. Chung, H.-N.; Rodriguez, S.D.; Carpenter, V.K.; Vulcan, J.; Bailey, C.D.; Nageswara-Rao, M.; Li, Y.; Attardo, G.M.; Hansen, I.A. Fat Body Organ Culture System in Aedes Aegypti, a Vector of Zika Virus. J. Vis. Exp. 2017. [CrossRef] [PubMed]

56. Wong, H.V.; Chan, Y.F.; Sam, I.-C.; Sulaiman, W.Y.W.; Vythilingam, I. Chikungunya Virus Infection of Aedes Mosquitoes. In Chikungunya Virus. Methods in Molecular Biology; Humana Press: New York, NY, USA, 2016; Volume 1426. 
57. Sirisena, P.D.N.N.; Kumar, A.; Sunil, S. Evaluation of Aedes aegypti (Diptera: Culicidae) Life Table Attributes Upon Chikungunya Virus Replication Reveals Impact on Egg-Laying Pathways. J. Med. Entomol. 2018, 55, 1580-1587. [CrossRef] [PubMed]

58. Thavara, U.; Tawatsin, A.; Pengsakul, T.; Bhakdeenuan, P.; Chanama, S.; Anantapreecha, S.; Molito, C.; Chompoosri, J.; Thammapalo, S.; Sawanpanyalert, P.; et al. Outbreak of chikungunya fever in Thailand and virus detection in field population of vector mosquitoes, Aedes aegypti (L.) and Aedes albopictus Skuse (Diptera: Culicidae). Southeast Asian J. Trop. Med. Public Health 2009, 40, 951-962. [PubMed]

59. Jain, J.; Kushwah, R.B.S.; Singh, S.S.; Sharma, A.; Adak, T.; Singh, O.P.; Bhatnagar, R.K.; Subbarao, S.K.; Sunil, S. Evidence for natural vertical transmission of chikungunya viruses in field populations of Aedes aegypti in Delhi and Haryana states in India-A preliminary report. Acta Trop. 2016, 162, 46-55. [CrossRef] [PubMed]

60. Chompoosri, J.; Thavara, U.; Tawatsin, A.; Boonserm, R.; Phumee, A.; Sangkitporn, S.; Siriyasatien, P. Vertical transmission of Indian Ocean Lineage of chikungunya virus in Aedes aegypti and Aedes albopictus mosquitoes. Parasit. Vectors 2016, 9, 227. [CrossRef]

61. Agarwal, A.; Dash, P.K.; Singh, A.K.; Sharma, S.; Gopalan, N.; Rao, P.V.L.; Parida, M.M.; Reiter, P. Evidence of Experimental Vertical Transmission of Emerging Novel ECSA Genotype of Chikungunya Virus in Aedes aegypti. PLoS Negl. Trop. Dis. 2014, 8, e2990. [CrossRef]

62. Wong, H.V.; Vythilingam, I.; Sulaiman, W.Y.W.; Lulla, A.; Merits, A.; Chan, Y.F.; Sam, I.C. Detection of persistent chikungunya virus RNA but not infectious virus in experimental vertical transmission in aedes aegypti from Malaysia. Am. J. Trop. Med. Hyg. 2016, 94, 182-186. [CrossRef]

63. Rosen, L.; Shroyer, D.A.; Tesh, R.B.; Freier, J.E.; Lien, J.C. Transovarial transmission of dengue viruses by mosquitoes: Aedes albopictus and Aedes aegypti. Am. J. Trop. Med. Hyg. 1983, 32, 1108-1119. [CrossRef]

64. Hardy, J.L.; Houk, E.J.; Kramer, L.D.; Reeves, W.C. Intrinsic factors affecting vector competence of mosquitoes for arboviruses. Annu. Rev. Entomol. 1983, 28, 229-262. [CrossRef] [PubMed]

65. Mascarenhas, M.; Garasia, S.; Berthiaume, P.; Corrin, T.; Greig, J.; Ng, V.; Young, I.; Waddell, L. A scoping review of published literature on chikungunya virus. PLoS ONE 2018, 13, e0207554. [CrossRef] [PubMed]

66. Althouse, B.M.; Guerbois, M.; Cummings, D.A.T.; Diop, O.M.; Faye, O.; Faye, A.; Diallo, D.; Sadio, B.D.; Sow, A.; Faye, O.; et al. Role of monkeys in the sylvatic cycle of chikungunya virus in Senegal. Nat. Commun. 2018, 9, 1-10. [CrossRef] [PubMed]

67. Eastwood, G.; Sang, R.C.; Guerbois, M.; Taracha, E.L.N.; Weaver, S.C. Enzootic circulation of chikungunya virus in East Africa: Serological evidence in non-human Kenyan primates. Am. J. Trop. Med. Hyg. 2017, 97, 1399-1404. [CrossRef] [PubMed]

68. Osterrieth, P.; Rathe, E.; Deleplanque-Liegeois, P. [Simultaneous isolation of the yellow fever and Chikungunya viruses at Bili (Haut-Uele, Belgian Congo)]. Ann. la Soc. Belge Med. Trop. 1961, 41, 207-212.

69. Vourc'H, G.; Halos, L.; Desvars, A.; Boué, F.; Pascal, M.; Lecollinet, S.; Zientara, S.; Duval, T.; Nzonza, A.; Brémont, M. Chikungunya antibodies detected in non-human primates and rats in three Indian Ocean islands after the 2006 ChikV outbreak. Vet. Res. 2014, 45, 1-5. [CrossRef] [PubMed]

70. Kading, R.C.; Borland, E.M.; Cranfield, M.; Powers, A.M. Prevalence of antibodies to alphaviruses and flaviviruses in free-ranging game animals and Non human primates in the greater Congo basin. J. Wildl. Dis. 2013, 49, 587-599. [CrossRef]

71. McCrae, A.W.; Henderson, B.E.; Kirya, B.G.; Sempala, S.D. Chikungunya virus in the Entebbe area of Uganda: Isolations and epidemiology. Trans. R. Soc. Trop. Med. Hyg. 1971, 65, 152-168. [CrossRef]

72. Guilherme, J.M.; Gonella-Legall, C.; Legall, F.; Nakoume, E.; Vincent, J. Seroprevalence of five arboviruses in Zebu cattle in the Central African Republic. Trans. R. Soc. Trop. Med. Hyg. 1996, 90, 31-33. [CrossRef]

73. Wolfe, N.D.; Kilbourn, A.M.; Karesh, W.B.; Rahman, H.A.; Bosi, E.J.; Cropp, B.C.; Andau, M.; Spielman, A.; Gubler, D.J. Sylvatic transmission of arboviruses among bornean orangutans. Am. J. Transplant. 2001, 64, 310-316. [CrossRef]

74. Sam, I.C.; Chua, C.L.; Rovie-Ryan, J.J.; Fu, J.Y.L.; Tong, C.; Sitam, F.T.; Chan, Y.F. Chikungunya virus in macaques, Malaysia. Emerg. Infect. Dis. 2015, 21, 1683-1685. [CrossRef]

75. Nakgoi, K.; Nitatpattana, N.; Wajjwalku, W.; Pongsopawijit, P.; Kaewchot, S.; Yoksan, S.; Siripolwat, V.; Souris, M.; Gonzalez, J.P. Dengue, Japanese encephalitis and Chikungunya virus antibody prevalence among captive monkey (Macaca nemestrina) colonies of Northern Thailand. Am. J. Primatol. 2014, 76, 97-102. [CrossRef] [PubMed] 
76. Marchette, N.J.; Rudnick, A.; Garcia, R.; MacVean, D.W. Alphaviruses in Peninusular Malaysia: I. Virus isolations and animal serology. Southeast Asian J. Trop. Med. Public Health 1978, 9, 317-329. [PubMed]

77. Inoue, S.; Morita, K.; Rr, M.; Jv, T.; Rrg, R. Distribution of three arbovirus antibodies among monkeys in the Philippines.pdf. J. Med. Primatol. 2003, 32, 89-94. [CrossRef] [PubMed]

78. Apandi, Y.; Nazni, W.A.; Azleen, Z.A.N.; Vythilingam, I.; Noorazian, M.Y.; Azahari, A.H.; Zainah, S.; Lee, H.L. The first isolation of chikungunya virus from non-human primates in Malaysia. J. Gen. Mol. Virol. 2009, 1, 35-39.

79. Moreira-Soto, A.; Carneiro, I.D.O.; Fischer, C.; Feldmann, M.; Kümmerer, B.M.; Silva, N.S.; Santos, U.G.; Souza, B.F.D.C.D.; Liborio, F.D.A.; Valença-Montenegro, M.M.; et al. Limited Evidence for Infection of Urban and Peri-urban Nonhuman Primates with Zika and Chikungunya Viruses in Brazil. mSphere 2018, 3, e00523-17. [CrossRef] [PubMed]

80. Bosco-Lauth, A.M.; Hartwig, A.E.; Bowen, R.A. Reptiles and amphibians as potential reservoir hosts of chikungunya virus. Am. J. Trop. Med. Hyg. 2018, 98, 841-844. [CrossRef] [PubMed]

81. Bosco-Lauth, A.M.; Nemeth, N.M.; Kohler, D.J.; Bowen, R.A. Viremia in North American mammals and birds after experimental infection with chikungunya viruses. Am. J. Trop. Med. Hyg. 2016, 94, 504-506. [CrossRef] [PubMed]

82. McIntosh, B.M. Antibody against Chikungunya virus in wild primates in Southern Africa. S. Afr. J. Med. Sci. 1970, 35, 65-74.

83. van Duijl-Richter, M.K.S.; Hoornweg, T.E.; Rodenhuis-Zybert, I.A.; Smit, J.M. Early events in chikungunya virus infection-From virus cell binding to membrane fusion. Viruses 2015, 7, 3647-3674. [CrossRef]

84. Wintachai, P.; Wikan, N.; Kuadkitkan, A.; Jaimipuk, T.; Ubol, S.; Pulmanausahakul, R.; Auewarakul, P.; Kasinrerk, W.; Weng, W.Y.; Panyasrivanit, M.; et al. Identification of prohibitin as a Chikungunya virus receptor protein. J. Med. Virol. 2012, 84, 1757-1770. [CrossRef]

85. Wintachai, P.; Thuaud, F.; Basmadjian, C.; Roytrakul, S.; Ubol, S.; Désaubry, L.; Smith, D.R. Assessment of flavaglines as potential chikungunya virus entry inhibitors. Microbiol. Immunol. 2015, 59, 129-141. [CrossRef]

86. Zhang, R.; Kim, A.S.; Fox, J.M.; Nair, S.; Basore, K.; Klimstra, W.B.; Rimkunas, R.; Fong, R.H.; Lin, H.; Poddar, S.; et al. Mxra8 is a receptor for multiple arthritogenic alphaviruses. Nature 2018, 557, 570-574. [CrossRef] [PubMed]

87. Ghosh, A.; Desai, A.; Ravi, V.; Narayanappa, G.; Tyagi, B.K. Chikungunya Virus Interacts with Heat Shock Cognate 70 Protein to Facilitate Its Entry into Mosquito Cell Line. Intervirology 2018, 60, 247-262. [CrossRef]

88. Fongsaran, C.; Jirakanwisal, K.; Kuadkitkan, A.; Wikan, N.; Wintachai, P.; Thepparit, C.; Ubol, S.; Phaonakrop, N.; Roytrakul, S.; Smith, D.R. Involvement of ATP synthase $\beta$ subunit in chikungunya virus entry into insect cells. Arch. Virol. 2014, 159, 3353-3364. [CrossRef] [PubMed]

89. Haby, M.M.; Pinart, M.; Elias, V.; Reveiz, L. Prevalence of asymptomatic Zika virus infection: A systematic review. Bull. World Health Organ. 2018, 96, 402. [CrossRef] [PubMed]

90. Bhatt, S.; Gething, P.W.; Brady, O.J.; Messina, J.P.; Farlow, A.W.; Moyes, C.L.; Drake, J.M.; Brownstein, J.S.; Hoen, A.G.; Sankoh, O.; et al. The global distribution and burden of dengue. Nature 2013, 496, 504-507. [CrossRef] [PubMed]

91. Ayu, S.M.; Lai, L.R.; Chan, Y.F.; Hatim, A.; Hairi, N.N.; Ayob, A.; Sam, I.-C. Seroprevalence survey of Chikungunya virus in Bagan Panchor, Malaysia. Am. J. Trop. Med. Hyg. 2010, 83, 1245-1248. [CrossRef]

92. Dupuis-Maguiraga, L.; Noret, M.; Brun, S.; Le Grand, R.; Gras, G.; Roques, P. Chikungunya disease: Infection-associated markers from the acute to the chronic phase of arbovirus-induced arthralgia. PLoS Negl. Trop. Dis. 2012, 6, e1446. [CrossRef] [PubMed]

93. WHO. Chikungunya Virus Fact Sheet. Available online: https://www.who.int/news-room/fact-sheets/ detail/chikungunya (accessed on 19 February 2019).

94. Rahman, M.; Jakaria, S.K.; Sayed, B.; Kabir, A.K.M.H.; Mallik, U.; Hasan, R.; Siddique, A.B.; Hossain, A.; Uddin, N.; Hassan, M.; et al. Clinical and Laboratory Characteristics of an Acute Chikungunya Outbreak in Bangladesh in 2017. Am. J. Trop. Med. Hyg. 2019, 100, 405-410. [CrossRef]

95. De Andrade, G.C.; Ventura, C.V.; Mello Filho, P.A.D.A.; Maia, M.; Vianello, S.; Rodrigues, E.B. Arboviruses and the eye. Int. J. Retin. Vitr. 2017, 3, 4. [CrossRef] [PubMed]

96. Fourie, E.D.; Morrison, J.G. Rheumatoid arthritic syndrome after chikungunya fever. S. Afr. Med. J. 1979, 56, 130-132. [PubMed] 
97. Aalst, V.; Nelen, C.M.; Goorhuis, A.; Stijnis, C.; Grobusch, M.P. Long-term sequelae of chikungunya virus disease: A systematic review. Travel Med. Infect. Dis. 2017, 15, 8-22. [CrossRef] [PubMed]

98. Rodríguez-Morales, A.J.; Cardona-Ospina, J.A.; Fernanda Urbano-Garzón, S.; Sebastian Hurtado-Zapata, J. Prevalence of Post-Chikungunya Infection Chronic Inflammatory Arthritis: A Systematic Review and Meta-Analysis. Arthritis Care Res. 2016, 68, 1849-1858. [CrossRef] [PubMed]

99. Economopoulou, A.; Dominguez, M.; Helynck, B.; Sissoko, D.; Wichmann, O.; Quenel, P.; Germonneau, P.; Quatresous, I. Atypical Chikungunya virus infections: Clinical manifestations, mortality and risk factors for severe disease during the 2005-2006 outbreak on Réunion. Epidemiol. Infect. 2009, 137, 534. [CrossRef] [PubMed]

100. Colavita, F.; Vita, S.; Lalle, E.; Carletti, F.; Bordi, L.; Vincenti, D.; Pozzetto, I.; Aiuti, M.; Vairo, F.; Capobianchi, M.R.; et al. Overproduction of IL-6 and Type-I IFN in a Lethal Case of Chikungunya Virus Infection in an Elderly Man During the 2017 Italian Outbreak. Open Forum Infect. Dis. 2018, 5, ofy276. [CrossRef] [PubMed]

101. Lemant, J.; Boisson, V.; Winer, A.; Thibault, L.; André, H.; Tixier, F.; Lemercier, M.; Antok, E.; Cresta, M.P.; Grivard, P.; et al. Serious acute chikungunya virus infection requiring intensive care during the reunion island outbreak in 2005-2006. Crit. Care Med. 2008, 36, 2536-2541. [CrossRef] [PubMed]

102. Renault, P.; Balleydier, E.; D’Ortenzio, E.; Bâville, M.; Filleul, L. Epidemiology of chikungunya infection on Reunion Island, Mayotte, and neighboring countries. Médecine Mal. Infect. 2012, 42, 93-101. [CrossRef]

103. Rajapakse, S.; Rodrigo, C.; Rajapakse, A. Atypical manifestations of chikungunya infection. Trans. R. Soc. Trop. Med. Hyg. 2010, 104, 89-96. [CrossRef]

104. Mercado, M.; Acosta-Reyes, J.; Parra, E.; Guzmán, L.; Beltrán, M.; Gasque, P.; Mejía-García, C.; Viasus, D. Renal involvement in fatal cases of chikungunya virus infection. J. Clin. Virol. 2018, 103, 16-18. [CrossRef]

105. Garg, T.; Sanke, S.; Ahmed, R.; Chander, R.; Basu, S. Stevens-Johnson syndrome and toxic epidermal necrolysis-like cutaneous presentation of chikungunya fever: A case series. Pediatr. Dermatol. 2018, 35, 392-396. [CrossRef] [PubMed]

106. Dutta, P.; Sharma, A. A case of atypical ophthalmoplegia after Chikungunya fever. Int. Ophthalmol. 2018, 38, 837-839. [CrossRef] [PubMed]

107. Mehta, R.; Gerardin, P.; de Brito, C.A.A.; Soares, C.N.; Ferreira, M.L.B.; Solomon, T. The neurological complications of chikungunya virus: A systematic review. Rev. Med. Virol. 2018, 28, e1978. [CrossRef] [PubMed]

108. Sharda, M.; Meena, H. Neurological complications in Chikungunya fever. J. Assoc. Phys. India 2007, 55, 765-769.

109. Singh, S.S.; Manimunda, S.P.; Sugunan, A.P.; Vijayachari, P. Four cases of acute flaccid paralysis associated with chikungunya virus infection. Epidemiol. Infect. 2008, 136, 1277-1280. [CrossRef] [PubMed]

110. Wielanek, A.C.; Monredon, J.D.; Amrani, M.E.; Roger, J.C.; Serveaux, J.P. Guillain-Barré syndrome complicating a chikungunya virus infection. Neurology 2007, 69, 2105-2107. [CrossRef]

111. Acevedo, N.; Waggoner, J.; Rodriguez, M.; Rivera, L.; Landivar, J.; Pinsky, B.; Zambrano, H. Zika virus, chikungunya virus, and dengue virus in cerebrospinal fluid from adults with neurological manifestations, Guayaquil, Ecuador. Front. Microbiol. 2017, 8, 1-6. [CrossRef]

112. Mehta, R.; Soares, C.N.; Medialdea-Carrera, R.; Ellul, M.; da Silva, M.T.T.; Rosala-Hallas, A.; Jardim, M.R.; Burnside, G.; Pamplona, L.; Bhojak, M.; et al. The spectrum of neurological disease associated with Zika and chikungunya viruses in adults in Rio de Janeiro, Brazil: A case series. PLoS Negl. Trop. Dis. 2018, 12, e0006212. [CrossRef]

113. Fros, J.; Pijlman, G. Alphavirus Infection: Host Cell Shut-Off and Inhibition of Antiviral Responses. Viruses 2016, 8, 166. [CrossRef]

114. Li, S.; Gong, M.; Zhao, F.; Shao, J.; Xie, Y.; Zhang, Y.; Chang, H. Type I Interferons: Distinct Biological Activities and Current Applications for Viral Infection. Cell. Physiol. Biochem. 2018, 51, 2377-2396. [CrossRef]

115. Schilte, C.; Couderc, T.; Chretien, F.; Sourisseau, M.; Gangneux, N.; Guivel-Benhassine, F.; Kraxner, A.; Tschopp, J.; Higgs, S.; Michault, A.; et al. Type I IFN controls chikungunya virus via its action on nonhematopoietic cells. J. Exp. Med. 2010, 207, 429-442. [CrossRef] [PubMed]

116. Broeckel, R.; Haese, N.; Messaoudi, I.; Streblow, D. Nonhuman Primate Models of Chikungunya Virus Infection and Disease (CHIKV NHP Model). Pathogens 2015, 4, 662-681. [CrossRef] [PubMed] 
117. Fros, J.J.; Liu, W.J.; Prow, N.A.; Geertsema, C.; Ligtenberg, M.; Vanlandingham, D.L.; Schnettler, E.; Vlak, J.M.; Suhrbier, A.; Khromykh, A.A.; et al. Chikungunya Virus Nonstructural Protein 2 Inhibits Type I/II Interferon-Stimulated JAK-STAT Signaling. J. Virol. 2010, 84, 10877-10887. [CrossRef] [PubMed]

118. Jones, P.H.; Maric, M.; Madison, M.N.; Maury, W.; Roller, R.J.; Okeoma, C.M. BST-2/tetherin-mediated restriction of chikungunya (CHIKV) VLP budding is counteracted by CHIKV non-structural protein 1 (nsP1). Virology 2013, 438, 37-49. [CrossRef] [PubMed]

119. Colavita, F.; Musumeci, G.; Caglioti, C. Human osteoblast-like cells are permissive for Zika virus replication. J. Rheumatol. 2018, 45, 443. [CrossRef] [PubMed]

120. Kvansakul, M. Viral Infection and Apoptosis. Viruses 2017, 9, 356. [CrossRef] [PubMed]

121. Krejbich-Trotot, P.; Denizot, M.; Hoarau, J.-J.; Jaffar-Bandjee, M.-C.; Das, T.; Gasque, P. Chikungunya virus mobilizes the apoptotic machinery to invade host cell defenses. FASEB J. 2011, 25, 314-325. [CrossRef] [PubMed]

122. Chow, A.; Her, Z.; Ong, E.K.S.; Chen, J.M.; Dimatatac, F.; Kwek, D.J.C.; Barkham, T.; Yang, H.; Rénia, L.; Leo, Y.S.; et al. Persistent arthralgia induced by Chikungunya virus infection is associated with interleukin-6 and granulocyte macrophage colony-stimulating factor. J. Infect. Dis. 2011, 203, 149-157. [CrossRef]

123. Kelvin, A.A.; Banner, D.; Silvi, G.; Moro, M.L.; Spataro, N.; Gaibani, P.; Cavrini, F.; Pierro, A.; Rossini, G.; Cameron, M.J.; et al. Inflammatory Cytokine Expression Is Associated with Chikungunya Virus Resolution and Symptom Severity. PLoS Negl. Trop. Dis. 2011, 5, e1279. [CrossRef]

124. Michlmayr, D.; Pak, T.R.; Rahman, A.H.; Amir, E.D.; Kim, E.; Kim-Schulze, S.; Suprun, M.; Stewart, M.G.; Thomas, G.P.; Balmaseda, A.; et al. Comprehensive innate immune profiling of chikungunya virus infection in pediatric cases. Mol. Syst. Biol. 2018, 14, e7862. [CrossRef]

125. Poo, Y.S.; Rudd, P.A.; Gardner, J.; Wilson, J.A.C.; Larcher, T.; Colle, M.A.; Le, T.T.; Nakaya, H.I.; Warrilow, D.; Allcock, R.; et al. Multiple Immune Factors Are Involved in Controlling Acute and Chronic Chikungunya Virus Infection. PLoS Negl. Trop. Dis. 2014, 8, e3354. [CrossRef] [PubMed]

126. Reddy, V.; Mani, R.S.; Desai, A.; Ravi, V. Correlation of plasma viral loads and presence of Chikungunya IgM antibodies with cytokine/chemokine levels during acute Chikungunya virus infection. J. Med. Virol. 2014, 86, 1393-1401. [CrossRef] [PubMed]

127. Venugopalan, A.; Ghorpade, R.P.; Chopra, A. Cytokines in Acute Chikungunya. PLoS ONE 2014, 9, e111305. [CrossRef] [PubMed]

128. Ng, L.F.P.; Chow, A.; Sun, Y.-J.; Kwek, D.J.C.; Lim, P.-L.; Dimatatac, F.; Ng, L.-C.; Ooi, E.-E.; Choo, K.-H.; Her, Z.; et al. IL-1 $\beta$, IL-6, and RANTES as Biomarkers of Chikungunya Severity. PLoS ONE 2009, 4, e4261. [CrossRef] [PubMed]

129. Hoarau, J.J.; Jaffar Bandjee, M.C.; Krejbich Trotot, P.; Das, T.; Li-Pat-Yuen, G.; Dassa, B.; Denizot, M.; Guichard, E.; Ribera, A.; Henni, T.; et al. Persistent Chronic Inflammation and Infection by Chikungunya Arthritogenic Alphavirus in Spite of a Robust Host Immune Response. J. Immunol. 2010, 184, 5914-5927. [CrossRef]

130. Teng, T.-S.; Kam, Y.-W.; Lee, B.; Hapuarachchi, H.C.; Wimal, A.; Ng, L.-C.; Ng, L.F.P. A Systematic Meta-analysis of Immune Signatures in Patients With Acute Chikungunya Virus Infection. J. Infect. Dis. 2015, 211, 1925-1935. [CrossRef] [PubMed]

131. Nair, S.; Poddar, S.; Shimak, R.M.; Diamond, M.S. Interferon Regulatory Factor 1 Protects against Chikungunya Virus-Induced Immunopathology by Restricting Infection in Muscle Cells. J. Virol. $2017,91$. [CrossRef]

132. Pruetz, J.D.; Socha, A.; Kante, D. New Range Record for the Lesser Spot-nosed Guenon (Cercopithecus petaurista) in Southeastern Senegal. Am. J. Primatol. 2010, 7, 64-66.

133. Lum, F.-M.; Ng, L.F.P. Cellular and molecular mechanisms of chikungunya pathogenesis. Antiviral Res. 2015, 120, 165-174. [CrossRef]

134. Hawman, D.W.; Stoermer, K.A.; Montgomery, S.A.; Pal, P.; Oko, L.; Diamond, M.S.; Morrison, T.E. Chronic Joint Disease Caused by Persistent Chikungunya Virus Infection Is Controlled by the Adaptive Immune Response. J. Virol. 2013, 87, 13878-13888. [CrossRef]

135. Teo, T.-H.; Lum, F.-M.; Claser, C.; Lulla, V.; Lulla, A.; Merits, A.; Renia, L.; Ng, L.F.P. A Pathogenic Role for CD4+ T Cells during Chikungunya Virus Infection in Mice. J. Immunol. 2013, 190, 259-269. [CrossRef] [PubMed] 
136. Partidos, C.D.; Weger, J.; Brewoo, J.; Seymour, R.; Borland, E.M.; Ledermann, J.P.; Powers, A.M.; Weaver, S.C.; Stinchcomb, D.T.; Osorio, J.E. Probing the attenuation and protective efficacy of a candidate chikungunya virus vaccine in mice with compromised interferon (IFN) signaling. Vaccine 2011, 29, 3067-3073. [CrossRef] [PubMed]

137. Mallilankaraman, K.; Shedlock, D.J.; Bao, H.; Kawalekar, O.U.; Fagone, P.; Ramanathan, A.A.; Ferraro, B.; Stabenow, J.; Vijayachari, P.; Sundaram, S.G.; et al. A DNA Vaccine against Chikungunya Virus Is Protective in Mice and Induces Neutralizing Antibodies in Mice and Nonhuman Primates. PLoS Negl. Trop. Dis. 2011, 5, e928. [CrossRef]

138. Messaoudi, I.; Vomaske, J.; Totonchy, T.; Kreklywich, C.N.; Haberthur, K.; Springgay, L.; Brien, J.D.; Diamond, M.S.; DeFilippis, V.R.; Streblow, D.N. Chikungunya Virus Infection Results in Higher and Persistent Viral Replication in Aged Rhesus Macaques Due to Defects in Anti-Viral Immunity. PLoS Negl. Trop. Dis. 2013, 7, e2343. [CrossRef] [PubMed]

139. Ekchariyawat, P.; Hamel, R.; Bernard, E.; Wichit, S.; Surasombatpattana, P.; Talignani, L.; Thomas, F.; Choumet, V.; Yssel, H.; Desprès, P.; et al. Inflammasome signaling pathways exert antiviral effect against Chikungunya virus in human dermal fibroblasts. Infect. Genet. Evol. 2015, 32, 401-408. [CrossRef] [PubMed]

140. Sourisseau, M.; Schilte, C.; Casartelli, N.; Trouillet, C.; Guivel-Benhassine, F.; Rudnicka, D.; Sol-Foulon, N.; Le Roux, K.; Prevost, M.C.; Fsihi, H.; et al. Characterization of reemerging chikungunya virus. PLoS Pathog. 2007, 3, 0804-0817. [CrossRef] [PubMed]

141. Wichit, S.; Diop, F.; Hamel, R.; Talignani, L.; Ferraris, P.; Cornelie, S.; Liegeois, F.; Thomas, F.; Yssel, H.; Missé, D. Aedes Aegypti saliva enhances chikungunya virus replication in human skin fibroblasts via inhibition of the type I interferon signaling pathway. Infect. Genet. Evol. 2017, 55, 68-70. [CrossRef]

142. Couderc, T.; Chrétien, F.; Schilte, C.; Disson, O.; Brigitte, M.; Guivel-Benhassine, F.; Touret, Y.; Barau, G.; Cayet, N.; Schuffenecker, I.; et al. A mouse model for Chikungunya: Young age and inefficient type-I interferon signaling are risk factors for severe disease. PLoS Pathog. 2008, 4, e29. [CrossRef]

143. Puiprom, O.; Morales Vargas, R.E.; Potiwat, R.; Chaichana, P.; Ikuta, K.; Ramasoota, P.; Okabayashi, T. Characterization of chikungunya virus infection of a human keratinocyte cell line: Role of mosquito salivary gland protein in suppressing the host immune response. Infect. Genet. Evol. 2013, 17, 210-215. [CrossRef]

144. Bernard, E.; Hamel, R.; Neyret, A.; Ekchariyawat, P.; Molès, J.P.; Simmons, G.; Chazal, N.; Desprès, P.; Missé, D.; Briant, L. Human keratinocytes restrict chikungunya virus replication at a post-fusion step. Virology 2015, 476, 1-10. [CrossRef]

145. Rudd, P.A.; Wilson, J.; Gardner, J.; Larcher, T.; Babarit, C.; Le, T.T.; Anraku, I.; Kumagai, Y.; Loo, Y.-M.; Gale, M.; et al. Interferon Response Factors 3 and 7 Protect against Chikungunya Virus Hemorrhagic Fever and Shock. J. Virol. 2012, 86, 9888-9898. [CrossRef] [PubMed]

146. Honda, K.; Yanai, H.; Negishi, H.; Asagiri, M.; Sato, M.; Mizutani, T.; Shimada, N.; Ohba, Y.; Takaoka, A.; Yoshida, N.; et al. IRF-7 is the master regulator of type-I interferon-dependent immune responses. Nature 2005, 434, 772-777. [CrossRef] [PubMed]

147. Osterlund, P.I.; Pietila, T.E.; Veckman, V.; Kotenko, S.V.; Julkunen, I. IFN Regulatory Factor Family Members Differentially Regulate the Expression of Type III IFN (IFN-) Genes. J. Immunol. 2007, 179, 3434-3442. [CrossRef] [PubMed]

148. Gasque, P.; Jaffar-Bandjee, M.C. The immunology and inflammatory responses of human melanocytes in infectious diseases. J. Infect. 2015, 71, 413-421. [CrossRef] [PubMed]

149. Parola, P.; de Lamballerie, X.; Jourdan, J.; Rovery, C.; Vaillant, V.; Minodier, P.; Brouqui, P.; Flahault, A.; Raoult, D.; Charrel, R.N. Novel chikungunya virus variant in travelers returning from Indian Ocean islands. Emerg. Infect. Dis. 2006, 12, 1493-1499. [CrossRef] [PubMed]

150. Her, Z.; Malleret, B.; Chan, M.; Ong, E.K.S.; Wong, S.C.; Kwek, D.J.C.; Tolou, H.; Lin, R.T.P.; Tambyah, P.A.; Renia, L.; et al. Active Infection of Human Blood Monocytes by Chikungunya Virus Triggers an Innate Immune Response. J. Immunol. 2010, 184, 5903-5913. [CrossRef] [PubMed]

151. Ruiz Silva, M.; Van Der Ende-Metselaar, H.; Mulder, H.L.; Smit, J.M.; Rodenhuis-Zybert, I.A. Mechanism and role of MCP-1 upregulation upon chikungunya virus infection in human peripheral blood mononuclear cells. Sci. Rep. 2016, 6, 1-9. [CrossRef] 
152. Ruiz Silva, M.; Aguilar Briseño, J.A.; Upasani, V.; van der Ende-Metselaar, H.; Smit, J.M.; Rodenhuis-Zybert, I.A. Suppression of chikungunya virus replication and differential innate responses of human peripheral blood mononuclear cells during co-infection with dengue virus. PLoS Negl. Trop. Dis. 2017, 11, e0005712. [CrossRef]

153. Laughhunn, A.; Huang, Y.-J.S.; Vanlandingham, D.L.; Lanteri, M.C.; Stassinopoulos, A. Inactivation of chikungunya virus in blood components treated with amotosalen/ultraviolet A light or amustaline/glutathione. Transfusion 2018, 58, 748-757. [CrossRef]

154. Tsetsarkin, K.A.; Sampson-Johannes, A.; Sawyer, L.; Kinsey, J.; Higgs, S.; Vanlandingham, D.L. Photochemical Inactivation of Chikungunya Virus in Human Apheresis Platelet Components by Amotosalen and UVA Light. Am. J. Trop. Med. Hyg. 2013, 88, 1163-1169. [CrossRef]

155. Ozden, S.; Huerre, M.; Riviere, J.P.; Coffey, L.L.; Afonso, P.V.; Mouly, V.; de Monredon, J.; Roger, J.C.; El Amrani, M.; Yvin, J.L.; et al. Human Muscle Satellite Cells as Targets of Chikungunya Virus Infection. PLoS ONE 2007, 2, e527. [CrossRef] [PubMed]

156. Lohachanakul, J.; Phuklia, W.; Thannagith, M.; Thongsakulprasert, T.; Smith, D.R.; Ubol, S. Differences in response of primary human myoblasts to infection with recent epidemic strains of Chikungunya virus isolated from patients with and without myalgia. J. Med. Virol. 2015, 87, 733-739. [CrossRef] [PubMed]

157. Deeba, F.; Islam, A.; Kazim, S.N.; Naqvi, I.H.; Broor, S.; Ahmed, A.; Parveen, S. Chikungunya virus: Recent advances in epidemiology, host pathogen interaction and vaccine strategies. Pathog. Dis. 2016, 74, ftv119. [CrossRef] [PubMed]

158. Manimunda, S.P.; Singh, S.S.; Sugunan, A.P.; Singh, O.; Roy, S.; Shriram, A.N.; Bharadwaj, A.P.; Shah, W.A.; Vijayachari, P. Chikungunya Fever, Andaman and Nicobar Islands, India. Emerg. Infect. Dis. 2007, 13, 1259-1260. [CrossRef] [PubMed]

159. Phuklia, W.; Kasisith, J.; Modhiran, N.; Rodpai, E.; Thannagith, M.; Thongsakulprasert, T.; Smith, D.R.; Ubol, S. Osteoclastogenesis induced by CHIKV-infected fibroblast-like synoviocytes: A possible interplay between synoviocytes and monocytes/macrophages in CHIKV-induced arthralgia/arthritis. Virus Res. 2013, 177, 179-188. [CrossRef] [PubMed]

160. Lokireddy, S.; Vemula, S.; Vadde, R. Connective tissue metabolism in chikungunya patients. Virol. J. 2008, 5, 31. [CrossRef] [PubMed]

161. Herrero, L.J.; Foo, S.-S.; Sheng, K.-C.; Chen, W.; Forwood, M.R.; Bucala, R.; Mahalingam, S. Pentosan Polysulfate: A Novel Glycosaminoglycan-Like Molecule for Effective Treatment of Alphavirus-Induced Cartilage Destruction and Inflammatory Disease. J. Virol. 2015, 89, 8063-8076. [CrossRef]

162. Kuo, S.C.; Wang, Y.M.; Ho, Y.J.; Chang, T.Y.; Lai, Z.Z.; Tsui, P.Y.; Wu, T.Y.; Lin, C.C. Suramin treatment reduces chikungunya pathogenesis in mice. Antiviral Res. 2016, 134, 89-96. [CrossRef]

163. Noret, M.; Herrero, L.; Rulli, N.; Rolph, M.; Smith, P.N.; Li, R.W.; Roques, P.; Gras, G.; Mahalingam, S. Interleukin 6, RANKL, and osteoprotegerin expression by chikungunya virus-infected human osteoblasts. J. Infect. Dis. 2012, 206, 455-457. [CrossRef]

164. Goupil, B.A.; McNulty, M.A.; Martin, M.J.; McCracken, M.K.; Christofferson, R.C.; Mores, C.N. Novel Lesions of Bones and Joints Associated with Chikungunya Virus Infection in Two Mouse Models of Disease: New Insights into Disease Pathogenesis. PLoS ONE 2016, 11, e0155243. [CrossRef]

165. Chen, W.; Foo, S.; Taylor, A.; Lulla, A.; Merits, A.; Hueston, L.; Forwood, M.R.; Walsh, N.C.; Sims, N.A.; Herrero, L.J.; et al. Bindarit, an Inhibitor of Monocyte Chemotactic Protein Synthesis, Protects against Bone Loss Induced by Chikungunya Virus Infection. J. Virol. 2015, 89, 581-593. [CrossRef] [PubMed]

166. Labadie, K.; Larcher, T.; Joubert, C.; Mannioui, A.; Delache, B.; Brochard, P.; Guigand, L.; Dubreil, L.; Lebon, P.; Verrier, B.; et al. Chikungunya disease in nonhuman primates involves long-term viral persistence in macrophages. J. Clin. Investig. 2010, 120, 894-906. [CrossRef] [PubMed]

167. Gardner, J.; Anraku, I.; Le, T.T.; Larcher, T.; Major, L.; Roques, P.; Schroder, W.A.; Higgs, S.; Suhrbier, A. Chikungunya Virus Arthritis in Adult Wild-Type Mice. J. Virol. 2010, 84, 8021-8032. [CrossRef] [PubMed]

168. Mazaud, R.; Salaün, J.J.; Montabone, H.; Goube, P.; Bazillio, R. Acute neurologic and sensorial disorders in dengue and Chikungunya fever. Bull. Soc. Pathol. Exot. Filiales 1971, 64, 22-30. [PubMed]

169. Arpino, C.; Curatolo, P.; Rezza, G. Chikungunya and the nervous system: What we do and do not know. Rev. Med. Virol. 2009, 19, 121-129. [CrossRef] [PubMed]

170. Thiruvengadam, K.V.; Kalyanasundaram, V.; Rajgopal, J. Clinical and pathological studies on chikungunya fever in Madras city. Indian J. Med. Res. 1965, 53, 729-744. [PubMed] 
171. Ganesan, K.; Diwan, A.; Shankar, S.K.; Desai, S.B.; Sainani, G.S.; Katrak, S.M. Chikungunya encephalomyeloradiculitis: Report of 2 cases with neuroimaging and 1 case with autopsy findings. Am. J. Neuroradiol. 2008, 29, 1636-1637. [CrossRef] [PubMed]

172. Dhanwani, R.; Khan, M.; Bhaskar, A.S.B.; Singh, R.; Patro, I.K.; Rao, P.V.L.; Parida, M.M. Characterization of Chikungunya virus infection in human neuroblastoma SH-SY5Y cells: Role of apoptosis in neuronal cell death. Virus Res. 2012, 163, 563-572. [CrossRef]

173. Solignat, M.; Gay, B.; Higgs, S.; Briant, L.; Devaux, C. Replication cycle of chikungunya: A re-emerging arbovirus. Virology 2009, 393, 183-197. [CrossRef]

174. Abraham, R.; Mudaliar, P.; Padmanabhan, A.; Sreekumar, E. Induction of Cytopathogenicity in Human Glioblastoma Cells by Chikungunya Virus. PLoS ONE 2013, 8, e75854. [CrossRef]

175. Abraham, R.; Singh, S.; Nair, S.R.; Hulyalkar, N.V.; Surendran, A.; Jaleel, A.; Sreekumar, E. Nucleophosmin (NPM1)/B23 in the Proteome of Human Astrocytic Cells Restricts Chikungunya Virus Replication. J. Proteome Res. 2017, 16, 4144-4155. [CrossRef] [PubMed]

176. Abere, B.; Wikan, N.; Ubol, S.; Auewarakul, P.; Paemanee, A.; Kittisenachai, S.; Roytrakul, S.; Smith, D.R. Proteomic analysis of chikungunya virus infected microgial cells. PLoS ONE 2012, 7, e34800. [CrossRef] [PubMed]

177. Wikan, N.; Sakoonwatanyoo, P.; Ubol, S.; Yoksan, S.; Smith, D.R. Chikungunya virus infection of cell lines: Analysis of the east, central and south African lineage. PLoS ONE 2012, 7, e31102. [CrossRef] [PubMed]

178. Chiam, C.W.; Chan, Y.F.; Ong, K.C.; Wong, K.T.; Sam, I.C. Neurovirulence comparison of chikungunya virus isolates of the Asian and East/Central/South African genotypes from Malaysia. J. Gen. Virol. 2015, 96, 3243-3254. [CrossRef] [PubMed]

179. Das, T.; Hoarau, J.J.; Bandjee, M.C.J.; Maquart, M.; Gasque, P. Multifaceted innate immune responses engaged by astrocytes, microglia and resident dendritic cells against Chikungunya neuroinfection. J. Gen. Virol. 2015, 96, 294-310. [CrossRef] [PubMed]

180. Fraisier, C.; Koraka, P.; Belghazi, M.; Bakli, M.; Granjeaud, S.; Pophillat, M.; Lim, S.M.; Osterhaus, A.; Martina, B.; Camoin, L.; et al. Kinetic Analysis of Mouse Brain Proteome Alterations Following Chikungunya Virus Infection before and after Appearance of Clinical Symptoms. PLoS ONE 2014, 9, e91397. [CrossRef] [PubMed]

181. Lim, P.J.; Chu, J.J.H. A Polarized Cell Model for Chikungunya Virus Infection: Entry and Egress of Virus Occurs at the Apical Domain of Polarized Cells. PLoS Negl. Trop. Dis. 2014, 8, e2661. [CrossRef] [PubMed]

182. Passoni, G.; Langevin, C.; Palha, N.; Mounce, B.C.; Briolat, V.; Affaticati, P.; De Job, E.; Joly, J.-S.; Vignuzzi, M.; Saleh, M.; et al. Imaging of viral neuroinvasion in the zebrafish reveals that Sindbis and chikungunya viruses favour different entry routes. Dis. Model. Mech. 2017, 10, 847-857. [CrossRef] [PubMed]

183. Mahendradas, P.; Avadhani, K.; Shetty, R. Chikungunya and the eye: A review. J. Ophthalmic Inflamm. Infect. 2013, 3, 1-9. [CrossRef]

184. Lin, J.; Chen, R.W.S.; Hazan, A.; Weiss, M. Chikungunya Virus Infection Manifesting as Intermediate Uveitis. Ocul. Immunol. Inflamm. 2018, 26, 680-682. [CrossRef]

185. Salceanu, S.O.; Raman, V. Recurrent chikungunya retinitis. BMJ Case Rep. 2018, 2018. [CrossRef] [PubMed]

186. Ulloa-Padilla, J.P.; Davila, P.J.; Izquierdo, N.J.; Garcia-Rodriguez, O.; Jimenez, I.Z. Ocular Symptoms and Signs of Chikungunya Fever in Puerto Rico. P. R. Health Sci. J. 2018, 37, 83-87. [PubMed]

187. Mahendradas, P.; Shetty, R.; Malathi, J.; Madhavan, H.N. Chikungunya virus iridocyclitis in Fuchs' heterochromic iridocyclitis. Indian J. Ophthalmol. 2010, 58, 545-547. [CrossRef] [PubMed]

188. Babu, K.; Murthy, G. Chikungunya virus iridocyclitis in Fuchs' heterochromic iridocyclitis. Indian J. Ophthalmol. 2012, 60, 73. [CrossRef] [PubMed]

189. Couderc, T.; Gangneux, N.; Chrétien, F.; Caro, V.; Le Luong, T.; Ducloux, B.; Tolou, H.; Lecuit, M.; Grandadam, M. Chikungunya virus infection of corneal grafts. J. Infect. Dis. 2012, 206, 851-859. [CrossRef] [PubMed]

190. Pal, P.; Fox, J.M.; Hawman, D.W.; Huang, Y.-J.S.; Messaoudi, I.; Kreklywich, C.; Denton, M.; Legasse, A.W.; Smith, P.P.; Johnson, S.; et al. Chikungunya Viruses That Escape Monoclonal Antibody Therapy Are Clinically Attenuated, Stable, and Not Purified in Mosquitoes. J. Virol. 2014, 88, 8213-8226. [CrossRef] [PubMed]

191. Chua, H.H.; Rashid, K.A.; Law, W.C.; Hamizah, A.; Chem, Y.K.; Khairul, A.H.; Chua, K.B. A fatal case of chikungunya virus infection with liver involvement. Med. J. Malaysia 2010, 65, 83-84. 
192. Davis, J.L.; Hodge, H.M.; Campbell, W.E. Growth of chikungunya virus in baby hamster kidney cell (BHK-21-clone 13) suspension cultures. Appl. Microbiol. 1971, 21, 338-341.

193. Gardner, J.; Rudd, P.A.; Prow, N.A.; Belarbi, E.; Roques, P.; Larcher, T.; Gresh, L.; Balmaseda, A.; Harris, E.; Schroder, W.A.; et al. Infectious chikungunya virus in the saliva of mice, monkeys and humans. PLoS ONE 2015, 10, 1-15. [CrossRef]

194. Niedrig, M.; Patel, P.; El Wahed, A.A.; Schädler, R.; Yactayo, S. Find the right sample: A study on the versatility of saliva and urine samples for the diagnosis of emerging viruses. BMC Infect. Dis. 2018, 18, 707. [CrossRef]

195. Musso, D.; Teissier, A.; Rouault, E.; Teururai, S.; de Pina, J.-J.; Nhan, T.-X. Detection of chikungunya virus in saliva and urine. Virol. J. 2016, 13, 102. [CrossRef] [PubMed]

196. Contopoulos-Ioannidis, D.; Newman-Lindsay, S.; Chow, C.; LaBeaud, A.D. Mother-to-child transmission of Chikungunya virus: A systematic review and meta-analysis. PLoS Negl. Trop. Dis. 2018, 12, 1-20. [CrossRef] [PubMed]

197. Gérardin, P.; Barau, G.; Michault, A.; Bintner, M.; Randrianaivo, H.; Choker, G.; Lenglet, Y.; Touret, Y.; Bouveret, A.; Grivard, P.; et al. Multidisciplinary Prospective Study of Mother-to-Child Chikungunya Virus Infections on the Island of La Réunion. PLoS Med. 2008, 5, e60. [CrossRef] [PubMed]

198. Touret, Y.; Randrianaivo, H.; Michault, A.; Schuffenecker, I.; Kauffmann, E.; Lenglet, Y.; Barau, G.; Fourmaintraux, A. Early maternal-fetal transmission of the Chikungunya virus. Presse Med. 2006, 35, 1656-1658. [CrossRef]

199. Grivard, P.; Le Roux, K.; Laurent, P.; Fianu, A.; Perrau, J.; Gigan, J.; Hoarau, G.; Grondin, N.; Staikowsky, F.; Favier, F.; et al. Molecular and serological diagnosis of Chikungunya virus infection. Pathol. Biol. 2007, 55, 490-494. [CrossRef] [PubMed]

200. Prata-Barbosa, A.; Cleto-Yamane, T.L.; Robaina, J.R.; Guastavino, A.B.; de Magalhães-Barbosa, M.C.; Brindeiro, R.D.M.; Medronho, R.A.; da Cunha, A.J.L.A. Co-infection with Zika and Chikungunya viruses associated with fetal death-A case report. Int. J. Infect. Dis. 2018, 72, 25-27. [CrossRef] [PubMed]

201. Charlier, C.; Beaudoin, M.-C.; Couderc, T.; Lortholary, O.; Lecuit, M. Arboviruses and pregnancy: Maternal, fetal, and neonatal effects. Lancet Child Adolesc. Heal. 2017, 1, 134-146. [CrossRef]

202. Platt, D.J.; Smith, A.M.; Arora, N.; Diamond, M.S.; Coyne, C.B.; Miner, J.J. Zika virus-related neurotropic flaviviruses infect human placental explants and cause fetal demise in mice. Sci. Transl. Med. 2018, 10, eaao7090. [CrossRef]

203. Bandeira, A.C.; Campos, G.S.; Rocha, V.F.D.; Souza, B.S.D.F.; Soares, M.B.P.; Oliveira, A.A.; de Abreu, Y.C.; Menezes, G.S.; Sardi, S.I. Prolonged shedding of Chikungunya virus in semen and urine: A new perspective for diagnosis and implications for transmission. IDCases 2016, 6, 100-103. [CrossRef]

204. Hua, C.; Combe, B. Chikungunya Virus-Associated Disease. Curr. Rheumatol. Rep. 2017, 19, 69. [CrossRef]

205. Vogels, C.B.F.; Rückert, C.; Cavany, S.M.; Perkins, T.A.; Ebel, G.D.; Grubaugh, N.D. Arbovirus coinfection and co-transmission: A neglected public health concern? PLOS Biol. 2019, 17, e3000130. [CrossRef] [PubMed]

206. WHO Guidelines on Clinical Management of Chikungunya Fever. Available online: http:/ /www.who.int/ iris/handle/10665/205178 (accessed on 19 February 2019).

207. Silva, J.V.J.; Ludwig-Begall, L.F.; Oliveira-Filho, E.F.D.; Oliveira, R.A.S.; Durães-Carvalho, R.; Lopes, T.R.R.; Silva, D.E.A.; Gil, L.H.V.G. A scoping review of Chikungunya virus infection: Epidemiology, clinical characteristics, viral co-circulation complications, and control. Acta Trop. 2018, 188, 213-224. [CrossRef] [PubMed]

208. Silva, L.A.; Dermody, T.S. Chikungunya virus: Epidemiology, replication, disease mechanisms, and prospective intervention strategies. J. Clin. Investig. 2017, 127, 737-749. [CrossRef] [PubMed]

209. Ferreira, A.C.; Reis, P.A.; de Freitas, C.S.; Sacramento, C.Q.; Villas Bôas Hoelz, L.; Bastos, M.M.; Mattos, M.; Rocha, N.; Gomes de Azevedo Quintanilha, I.; da Silva Gouveia Pedrosa, C.; et al. Beyond Members of the Flaviviridae Family, Sofosbuvir Also Inhibits Chikungunya Virus Replication. Antimicrob. Agents Chemother. 2018, 63, e01389-18. [CrossRef] [PubMed]

210. Franco, E.J.; Rodriquez, J.L.; Pomeroy, J.J.; Hanrahan, K.C.; Brown, A.N. The effectiveness of antiviral agents with broad-spectrum activity against chikungunya virus varies between host cell lines. Antivir. Chem. Chemother. 2018, 26, 204020661880758. [CrossRef] [PubMed] 
211. Chopra, A.; Saluja, M.; Venugopalan, A. Effectiveness of Chloroquine and Inflammatory Cytokine Response in Patients With Early Persistent Musculoskeletal Pain and Arthritis Following Chikungunya Virus Infection. Arthritis Rheumatol. 2014, 66, 319-326. [CrossRef] [PubMed]

212. de Lamballerie, X.; Ninove, L.; Charrel, R.N. Antiviral treatment of chikungunya virus infection. Infect. Disord. Drug Targets 2009, 9, 101-104. [CrossRef]

213. Khan, M.; Santhosh, S.R.; Tiwari, M.; Lakshmana Rao, P.V.; Parida, M. Assessment of in vitro prophylactic and therapeutic efficacy of chloroquine against chikungunya virus in vero cells. J. Med. Virol. 2010, 82, 817-824. [CrossRef]

214. Roques, P.; Thiberville, S.D.; Dupuis-Maguiraga, L.; Lum, F.M.; Labadie, K.; Martinon, F.; Gras, G.; Lebon, P.; $\mathrm{Ng}$, L.F.P.; de Lamballerie, X.; et al. Paradoxical effect of chloroquine treatment in enhancing chikungunya virus infection. Viruses 2018, 10, 268. [CrossRef]

215. Smith, S.A.; Silva, L.A.; Fox, J.M.; Flyak, A.I.; Kose, N.; Sapparapu, G.; Khomandiak, S.; Ashbrook, A.W.; Kahle, K.M.; Fong, R.H.; et al. Isolation and Characterization of Broad and Ultrapotent Human Monoclonal Antibodies with Therapeutic Activity against Chikungunya Virus. Cell Host Microbe 2015, 18, 86-95. [CrossRef]

216. Reyes-Sandoval, A. 51 years in of Chikungunya clinical vaccine development: A historical perspective. Hum. Vaccin. Immunother. 2019. [CrossRef] [PubMed]

217. Plante, K.; Wang, E.; Partidos, C.D.; Weger, J.; Gorchakov, R.; Tsetsarkin, K.; Borland, E.M.; Powers, A.M.; Seymour, R.; Stinchcomb, D.T.; et al. Novel Chikungunya Vaccine Candidate with an IRES-Based Attenuation and Host Range Alteration Mechanism. PLoS Pathog. 2011, 7, e1002142. [CrossRef]

218. Wang, E.; Kim, D.Y.; Weaver, S.C.; Frolov, I. Chimeric Chikungunya Viruses Are Nonpathogenic in Highly Sensitive Mouse Models but Efficiently Induce a Protective Immune Response. J. Virol. 2011, 85, 9249-9252. [CrossRef] [PubMed]

219. Nougairede, A.; De Fabritus, L.; Aubry, F.; Gould, E.A.; Holmes, E.C.; de Lamballerie, X. Random Codon Re-encoding Induces Stable Reduction of Replicative Fitness of Chikungunya Virus in Primate and Mosquito Cells. PLoS Pathog. 2013, 9, e1003172. [CrossRef] [PubMed]

220. Achee, N.L.; Grieco, J.P.; Vatandoost, H.; Seixas, G.; Pinto, J.; Ching-NG, L.; Martins, A.J.; Juntarajumnong, W.; Corbel, V.; Gouagna, C.; et al. Alternative strategies for mosquito-borne arbovirus control. PLoS Negl. Trop. Dis. 2019, 13, e0006822. [CrossRef]

(C) 2019 by the authors. Licensee MDPI, Basel, Switzerland. This article is an open access article distributed under the terms and conditions of the Creative Commons Attribution (CC BY) license (http://creativecommons.org/licenses/by/4.0/). 